\title{
LAS PINTURAS PERDIDAS DE LA CATEDRAL DE MEXICO
}

Por Xavier Moyssén

\section{A Francisco de la Maza}

El incendio que sufrió la catedral de México el 18 de enero de 1967, destruyó un grupo de obras de indudable importancia para la historia de la pintura de México. La pérdida fue absoluta. Las pinturas correspondían a los tres siglos del virreinato novoespañol y representaban los diversos estilos artísticos que en tiempo tan prolongado se sucedieron. Desde el cuadro de caballete de pequeño formato, hasta la gran composición de carácter mural, tal fue el conjunto de obras que el tesoro artístico de la catedral perdió para siempre.

El grupo principal se localizaba en la parte más castigada por el incendio: el coro y el altar del perdón. Otras obras fueron dañadas o destruidas como si ello hubiera obedecido al mandato de una adversidad trágica para la catedral. Inexplicablemente desapareció la pintura de Juan Correa sobre la Asunción y coronación de la Virgen, que se encontraba colocada arriba de la puerta mayor (figs. 12 y 13); de otros cuadros que sobre el mismo muro existían no quedó huella alguna, pues hasta donde mis informes llegan, nunca fueron registrados por quienes se han ocupado del tesoro catedralicio; si del cuadro de Correa contamos con las fotografías que hace años tomó don Luis Márquez, de las otras telas sólo queda el recuerdo vago de su existencia. A la adversidad se debe la desaparición de las pinturas murales que Rafael Jimeno y Planes terminó en 1810 en la cúpula; el humo que el incendio produjo se alojó en ella cual si se tratara de una cámara en la que se encontraba la salida lógica hacia el exterior, el resultado no pudo ser otro. La densa nube de humo se desplazó hacia el retablo de la capilla de los reyes, cuando se abrieron las puertas de la portada principal; la masa de humo caliente dañó y puso en peligro el gran retablo; de las dos pinturas que éste tiene, ambas de Juan Rodríguez Juárez, la que representa La asunción de la Virgen, estuvo a punto de perderse por completo. Aunque notablemente ennegrecido este enorme cuadro (mide $6.19 \times 2.56 \mathrm{mts}$ ) ha regresado a su sitio después de una cuidadosa restauración.

Por una afortunada casualidad he logrado reunir las fotografias de las pinturas principales que en el trágico siniestro se perdieron; aun 
cuando no todas son de idéntica calidad, gracias a ellas guardaremos el testimonio documental de tales obras.

Simón Pereyns. Virgen del Perdón. Oleo sobre tabla (2.60 x $2.13 \mathrm{mts} .$. aproximadamente).

Del conjunto de pinturas perdidas quizá ninguna era tan conocida y estimada como la que representaba a la Virgen con el Niño en compañía de San José y Santa Ana. Este cuadro de indudable interés para el arte de la Nueva España, era conocido como de la Virgen del Perdón (fig. 1), no porque esa fuera su correcta advocación, sino por el hecho de estar colocado sobre el Altar del Perdón de Animas y no de penitenciarios del Santo Oficio, como escribió Manuel Toussaint en su monumental monografía sobre la catedral. * La colocación del cuadro y otras circunstancias motivaron una curiosa y enredada leyenda en torno a la pintura y su autor.

La tabla fue pintada por el flamenco Simón Pereyns, activo en México entre 1566 y $1594 .{ }^{1}$ Durante años los historiadores del arte que se ocuparon de ella la adjudicaban, basándose principalmente en la leyenda, a Pereyns, mas ninguno había logrado ver en realidad la firma, a excepción de Manuel G. Revilla, el cual escribió en 1892 lo siguiente: "La Virgen del Perdón de la Catedral de México es de Pereyns, puesto que está firmada con el nombre castellanizado: Perines", 2 lo que indica, como veremos, que él la vio. No deja de llamar la atención que don Manuel Toussaint no haya localizado la firma en la ocasión en que observó el cuadro sin el vidrio; sorprende también de que dudara en adjudicarlo a Pereyns con certeza, en sus obras básicas sobre la pintura, el arte colonial y la catedral misma. La célebre obra se llegó a otorgar incluso, a Francisco de Ibía o de Zumaya, por Francisco Fernández del Castillo, quien llegó a decir que identificó la firma de Ibía en el cua-

- Este altar, al parecer, siempre estuvo dispuesto en el eje de la puerta llamada del Perdón; pues a él se refiere en 1570, fray Diego Durán, "... la puerta de la Iglesia Mayor, que llaman del Perdón, donde está el altar de la indulgencia..." Vide: Historia de las Indios de Nueva España e Islas de la Tierra Firme. T. 1, p. 154. Editorial Porrúa. México, 1967.

1 Para mayores noticias sobre el artista consúltese: Pintura Colonial en México, de Manuel Toussaint, pp. 54-62. México, 1965.

2 Manuel G. Revilla, El arte en México, p. 104. Segunda edición. Librería Universal de Porrúa Hermanos. México, 1923. La primera edición es de 1893. Guardo noticias que no he logrado corroborar, que la firma también fue vista por el señor Alfon. so Vázquez Vergara, director que fue del antiguo Museo de la Catedral. 
dro. ${ }^{3}$ No faltó también quien la adjudicara a Baltasar de Echave Orio: "Consideramos que hay bastante fundamento para considerar este cuadro como de Echave, lo mismo que el San Sebastián que se encuentra arriba de él..." 4 En julio de 1965 en compañía de Justino Fernández tuve oportunidad de estudiar la tabla con cierto detenimiento in situ y sin el vidrio que le protegía; en esa ocasión localizamos la firma, se encontraba en un escalón previo al sitio del trono de la Virgen; con letras versales tipográficas se leía en una primera línea: XIMON PERINES y abajo: PINXIEVAT. El pintor castellanizó su apellido como lo advirtió Revilla. 5

Una de las cuestiones más debatidas respecto a la pintura, como habrá de verse, era si ésta se había hecho o no, sobre los maderos de la puerta de una prisión, toda vez que en la gran tabla se advertían las huellas de los chapetones de la supuesta puerta. Las huellas que por lo demás cualquiera podía notarlas a cierta distancia, apareclan horizontalmente a pesar de la tela y la pintura aplicada, lo cual permitía suponer que Pereyns preparó su cuadro aprovechando los maderos de una puerta, sin que ésta hubiera sido, como quiere la leyenda, precisamente la de su prisión.

A Simón Pereyns se le encarceló en efecto en 1568, por orden del Tribunal de la Fe, sometiéndole a tormento. La causa se abrió en realidad por mezquinas envidias profesionales, por la denuncia que en su contra hicieron el pintor Francisco de Morales y su mujer, a propósito de unas cuestiones que si hoy nos parecen baladfes no lo eran de ninguna manera en esa época. El acusado a pesar del tormento salió con bien del terrible tribunal; se le condenó únicamente a que trabajara para la catedral vieja de México, sitio en el que funcionaba la Inquisición antes de su establecimiento definitivo en el país, en 1571. En el proceso seguido al flamenco se lee la sentencia: "... que pinte a su costa el retablo de nuestra señora de la Merced de esta Santa Iglesia..." ' Del cita-

3 En el periólico El Universal, del 5 de abril de 1924.

4 Francisco Diez Barroso, El arte en Nueva España, p. 259. México, 1921.

5 Tanto el cuadro de la Virgen del Perdón, como el de San Sebastiin, en el mismo altar, fueron bárbaramente "restaurados" por un pintor español llamado Francisco Molina. El atentado cometido lo comprobé con pesadumbre, en compañia de Justino Fernández.

6 El manuscrito original del proceso inquisitorial de Simón Pereyns, lo poseia a fines del siglo pasado, José María de Agreda y Sánchez; él mismo se lo mostró a Manuel G. Revilla. Andando el tiempo el manuscrito fue propiedad de Luis González Obregón, quien obsequió una copıa a Manuel Toussaint. el cual la publicó con otros documentos del mismo artista. Vide: Proceso y denuncias contra Simón Pereyns 
do proceso provienen las mayores noticias que sobre el pintor se conocen.

El proceso y la condena dictada contra Simón Pereyns, son las bases sobre las que se originó tanto la leyenda como la confusión en torno al cuadro impropiamente llamado de la Virgen del Perdón, pues como se ha visto al maestro flamenco se le condenó a pintar un retablo de la Virgen de la Merced, tema iconográfico bien distinto al del desaparecido cuadro de la catedral. Pero continuemos adelante,

Aparte de la obra que se le ordenó hacer a Simón Pereyns, se conservan noticias de otras pinturas que trabajó para la catedral vieja. En 1588 se levantó un inventario y en él se dice que había de Pereyns "Un retablo grande de madera... y la imagen de en medio al olio de pinzel en un tablón grande, de Nuestra Sra. de los Remedios y en la peaña los cuatro evangelistas a media talla dorado y estofado que es el que estaba en el altar mayor de la yglesia vieja; está agora en el cabildo. Hizole Simón Prins (sic)". 7 Al cuadro de la Virgen de la Merced hay que agregar el que cita el inventario, mas la tabla destruida en 1967, con lo cual se concluye que Pereyns pintó para la catedral tres cuadros de la Virgen con distintas advocaciones, de dos de ellos, por lo menos, sabemos que se encontraban en el centro de retablos. El maestro flamenco disfrutaba de prestigio como hábil pintor y el cabildo catedralicio bien pudo encomendarle diversas obras, como el San Cristóbal que aún existe y que fechó en 1588; mas no deja de extrañar que se le encargaran tres grandes pinturas con el tema central de la Virgen.

No existe noticia exacta que indique como era el Altar del Perdón en la catedral del siglo xvil; Isidro Sariñana nada dice al respecto en su barroca descripción. ${ }^{8} \mathrm{Sin}$ embargo, hay una interesantísima noticia en el Diario de Gregorio M. de Guijo: “Altar nuevo. Dicho dia (15 de agosto de 1650) celebraron los hermanos de la hermandad de Nuestra Señora del Perdón del altar de la catedral, la fiesta de las Nieves, que fue este dia, y estrenaron con colateral y renuevo de pincel de la Virgen y lienzos de los doce apóstoles, y le añadieron los cuatro evangelistas; fue muy solemne fiesta, que tuvo su principio desde el año pasado de 1648 . . " 8

en la Inquisición de México. Suplemento al número 2 de los Anales del IIE. México, 1938.

i Esta noticia la dio Manuel Toussaint en su Pintura Colonial en México, p. 60.

8 La catedral de México en 1668. Noticia breve de la solemne, deseada, última dedi. cación del Templo Metropolitano de México. Edición de Francisco de la Maza. Su. plemento 2 del número 37 de los Anales del IIE. México, 1968.

${ }^{9}$ T-I, 1648.1654. Edición y prólogo de Manuel Romero de Terreros. Colección de Fscritores Mexicanos. Editorial Porrúa, México, 1953. 
El Altar del Perdón tal como llegó hasta el siglo actual, fue obra de Jerónimo de Balbás; se dedicó el 29 de junio de 1737 . Balbás por razones que se desconocen incluyó dentro de la composición de su retablo, tres pinturas procedentes de épocas anteriores: dos del siglo XvI, la tabla de Pereyns y el San Sebastián; del siglo siguiente el Divino Rostro, del dominico Alonso López de Herrera. Lo único que se sabe con certeza, es que en torno a la pintura del flamenco existía una efectiva devoción, gracias a la cual en la ciudad circulaba una estampa grabada por Salvador Zapata en 1764; estampa que el capuchino fray Francisco de Ajofrín adquirió seguramente en la propia catedral, durante su visita a la capital, la cual agregó, entre otras, a su interesante Diario. Este curioso grabado no sólo reproduce torpemente el cuadro, también lo altera en su composición pues en la parte inferior incluye dos "ánimas" que están en espera de alcanzar el perdón de la Virgen. ${ }^{10}$ No es éste el único caso en que se copió la célebre pintura alterándola en su composición original; don Manuel Toussaint habla de una copia hecha por Ventura de Miranda, activo hacia 1723, "... yo poseo un cuadrito suyo con una mala copia de la Virgen del Altar del Perdón a la que ha agregado a San Joaquín". Vide: Pintura Colonial en México, página 145. A propósito del estreno del retablo de Jerónimo de Balbás y del cuadro de Pereyns, se transcribe a continuación la noticia que apareció en lá Gaceta de México: "El 19 se dedicó el Retablo que hace espalda al coro, y mira a las tres puertas principales de la Santa Iglesia Metropolitana, cuya proporcionada simetría, sube desde el soclo, que es de piedra de cantería y está primorosamente tallado, y dando lugar a compuestos estípites, cornisas, repisas, molduras, sobrepuestos, medallones, nichos con airosas estatuas de santos clérigos, remata en perfecto medio punto, en que se ve la Imagen de S.S. y a plomo en el principal lugar la que lo es de estos cultos Milagrosa Imagen de Ntra. Señora, pintada con gran destreza en una puerta; dicen que por mano de un preso que se hallaba en la Cárcel de Corte y que habiéndosele concedido libertad por esta

10 Fray Francisco de Ajofrín. Diario del viaje que por orden de la sagrada congre. gación de Propaganda Fide hizo a la América Septentrional en el siglo XVIII el Padre.. El grabado aparece reproducido en la página 157 del tomo I y al pie lleva la siguiente inscripción: V.R. de la milagrosíssima Imagen de Ntra. Sra. del Perdón que se venera en la Santa Iglesia Cathedral de México. Año de 1764. A dev. del Lic. S.D. Nicolás Ximenes, Cura de Pasoyuca y Colector. Zapata ex... Archivo Dorumental Español. Madrid, 1958. 
DOI: http://dx.doi.org/10.22201/iie.18703062e.1970.39.916

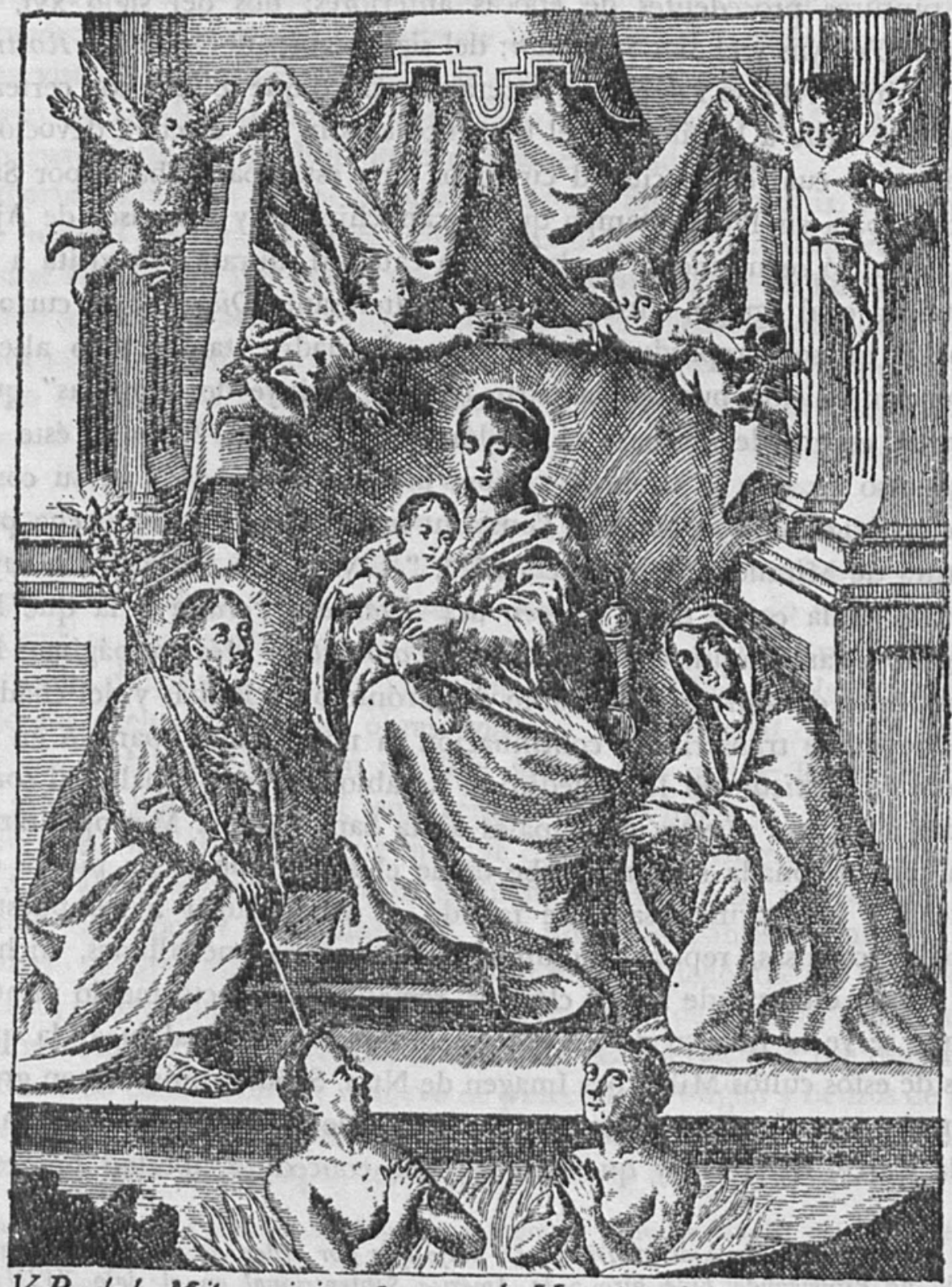

V.R. de la Milagrosissima Imagen de NFa. Sia. del Perdon que se ve

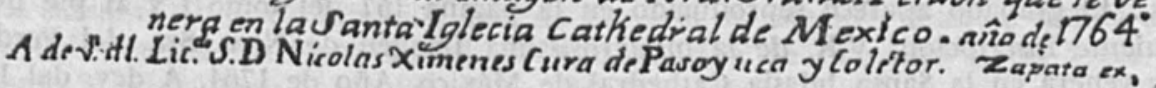


causa, por la misma se llamó, como hasta ahora se llama Nuestra Señora del Perdón; ciñósele este día su rico marco de plata nuevamente emblanquecido y bruñido y se le pusieron nuevos corpulentos vidrios para su mayor decencia la resguardan y en su sacristía, que (con la del lado del Evangelio) quedó más clara y espaciosa, se estrenaron (a solicitud de su colector) exquisitos ornamentos, obras, amitos, síngulos, y otros curiosos adherentes." 11

Una noticia más procedente del siglo xvin sobre Pereyns y su cuadro del Altar del Perdón, la ofrece el bachiller Juan de Viera en la descripción que hace de la catedral: "A espaldas del Choro está el altar que llaman del Perdón y en él se venera una imagen de Nuestra Señora la Virgen María, que está colocada en un prodigioso retablo que sube en lo alto más de veinticinco varas, y remata en un medio punto donde se dexan ver las Armas Reales que sobresalen más de ocho varas en el aire, sobre las espaldas del Choro y a los lados estatuas de más del tamaño natural. La Santísima Imagen de que voy hablando tiene el Santo Niño en los brazos y es tradición mui antigua que la tenían unos judíos pintada en la puerta de una caballeriza; lo cierto es que al pie de esta hermosa pintura, se perciben unas cabezas de clavos de la puerta y éstos los ve cualquiera sin ninguna dificultad. Tiene un marco de plata maciza de mucho valor y aprecio, con sus cristales correspondientes..." 12

De todo lo anotado hasta aquí se sacan las siguientes conclusiones: Simón Pereyns fue condenado a pintar por la Inquisición y para la catedral vieja, un retablo de la Virgen de la Merced, mas se ignora si llegó a desarrollar tal cuadro, llamado retablo quizá por su tamaño, o bien, si se le cambió el tema de acuerdo con las mismas autoridades; de ser así, la obra pintada por el flamenco fue la que destruyó el fuego, es decir la Virgen con el Niño acompañados por San José y Santa Ana. Como el tema central era la Virgen, la advocación del Perdón no se contrapuso al ser colocado el cuadro en el altar de ese título. En la sentencia se le dio al artista la ciudad por prisión, "... y que en el ynterin que el dicho retablo pinta no salga desta ciudad en sus pies ny en agenos..." , mas no se indica que debe permancer encerrado en una celda, por lo tanto, él no pintó en la puerta de la misma el gran cuadro. Ma-

11 Gaceta de México. Desde primero liasta fines de junio de 1737. Número 115.

12 Breve compendiosa narración de la ciudad de México. Corte y cabeza de toda la América Scptentrional, que a instancias de un amigo, bosquejó el bachiller Don Juan de Viera. Año de 1777. Prólogo y notas de Gonzalo Obregón. pp. 34-35. Editorial Guaranía. México-Buenos Aires, 1952. 
nuel Toussaint observó esto claramente al escribir: "El hecho de que la pintura esté en una tabla con clavos de puerta, como puede observarlo cualquier espectador, indica sólo que no hubo una tabla bastante grande para que el procesado cumpliese su sentencia y, entonces, en las hojas de una puerta cuyos clavos fueron aplanados a fuerza de martillo y sobre la cual se puso una tela, tuvo que pintar su cuadro." 13 En todo coincidimos con Toussaint, salvo en que los clavos no existian, fueron extraídos y las tablas que formaban el cuadro, estaban ensambladas a la manera común del siglo xvi.

En el inventario de 1588, se cita un cuadro de Nuestra Señora de los Remedios, de Pereyns, mas por desgracia no se hace ninguna descripción del mismo; o se trataba de otra obra o hubo un error en la advocación, por improbable que parezca. En cambio no parece existir ninguna duda, que es a la tabla de Pereyns a la que se refiere Guijo al hablar de "la hermandad de Nuestra Señora del Perdón", del altar que traian y del “... renuevo de pincel de la Virgen ..." El cuadro se renovó o repintó, por dos causas: la devoción y culto que tenia, mas su apreciable calidad artística. Esto mismo fue lo que se impuso, con toda seguridad, para que Balbás lo incluyera en su barroco retablo de 1737; pues no existe duda que al mismo cuadro se refieren tanto el redactor de la Gaceta de México, como el bachiller Juan de Viera; si bien uno y otro contribuyeron a embrollar una leyenda que venía de lejos; en la Gaceta se dijo que lo había pintado un preso de la Cárcel de Corte, dato falso como el del bachiller que escribió, que el cuadro lo tenian "unos judios (pintado) en la puerta de una caballeriza..."

La leyenda sobre el origen del cuadro del Altar del Perdón y su autor, debió mantenerse viva a lo largo del siglo xIx, unida por lo demás a una devoción afectiva, como la del "Colector de Animas", don José María Toral, quien en 1815 mandó grabar la lámina que aquí se reproduce ${ }^{14}$ (fig. 5). Luis González Obregón recogió la leyenda a finales del siglo pasado y la relacionó correctamente al ya citado proceso inquisitorial de Simón Pereyns y así prácticamente llegó hasta nuestros días. ${ }^{15}$ El mag-

13 La catedral de México y el sagrario metropolitano. Su historia, su tesoro, su arte. Comisión Diocesana de Orden y Decoro. México, 1948, p. 122.

14 Una inscripción manuscrita con tinta negra, que tenía el marco de madera, ofrecía la siguiente noticia: "Promovió este vidrio y se puso en 26 de mayo del año 1856. Eusebio Orihuela. Siendo colector el señor don José María Toral."

15 Luis González Obregón, México Viejo. Noticias históricas, tradiciones, Ieyendas y costumbres. Cap. xi, "La Virgen del Perdón", pp. 93-98. Paris, 1900. 
nifico dibujo que Julio Ruelas hizo por encargo de González Obregón, dio mayor veracidad a la leyenda (fig. 6).

Sobre el mérito artístico del famoso cuadro no vamos a insistir, de ello se han ocupado doctamente varios historiadores, con don Manuel Toussaint a la cabeza. Sin embargo, he aquí lo más importante que se ha escrito. La "Virgen del Perdón", escribió Diego Angulo Iñiguez, "preséntasenos en su trono con el Salvador sobre sus piernas, coronada por dos ángeles y adorada por dos santos. En el fondo, de arquitectura en forma de ábside cubierto de pilastras, parece percibirse un vago eco de la famosa Virgen de baldaquino de la Pitti, y, en la actitud del Niño, el reflejo del que en brazos de la Vingen de Foligno pugna en el Vaticano por lanzarse al espacio. Quizá llegaron a él ambos motivos a través de alguna visión en que se dieron ya fundidas esas dos obras capitales del maestro de Urbino, pero de ellas proceden el sentido de la monumentalidad y la inquietud infantil triunfantes en la tabla mejicana" 16 (figs. I a 4). La perspicaz observación de Angulo fñiguez se corroboró en parte por un grabado de Marcantonio Raimondi, que dio a conocer Santiago Sebastián. ${ }^{17}$ El grabado reproduce un estudio preparatorio de la Madona di Foligno de Rafael; una copia bien pudo haberla utilizado Simón Pereyns. Un interesante estudio sobre la composición del cuadro, fue hecho por Justino Fernández, para quien "las estructuras o trazados de las composiciones pictóricas tienen un interés fundamental y su estudio es indispensable si es que se pretende llevar al cabo análisis formales completos". 18

Anónimo. San Sebastián. Oleo sobre tela (1.88 x $1.15 \mathrm{mts}$.).

Entre las pinturas del siglo xvı existentes en la catedral, sobresalia el cuadro de San Sebastián que se hallaba en la parte superior del Altar del Perdón (figs. 8 y 9). A pesar de una torpe restauración a que se le sometió y que casi termina con la pintura, el cuadro siempre se imponía al ojo del conocedor por su indudable calidad. Aunque no se cuenta con la documentación deseable sobre el origen de la tabla, se pucde aceptar lo que Toussaint escribió al respecto: "Debe observarse que existió en la catedral vieja de México una confradía de San Sebastián

16 Historia del Arte Hispanoamericano, t. 11, p. 382, Salvat Editores, S. A. Barce. lona, 1950.

17 "Nuevo grabado en la obra de Pereyns", en Anales del IIE. Vol. Ix, número 35, pp. 45*46, México, 1966.

18 Vide, "Composiciones barrocas de dos pinturas en el Altar del Perdón", en Anales del IIE. Vol. IX, núm. 35, pp. 41-43, con dos ilustraciones. México, 1966. 
fechada antes de 1565. Para tal confradía se puede haber pintado el cuadro." 10

¿Quién fue el autor de esta singular obra? Desde el siglo XIX se lanzaron infundadas opiniones para adjudicar gratuitamente el cuadro a diversos artistas. Sin argumentos convincentes se le dio la paternidad a Francisco de Ibía o de Zumaya, quien trabajó aquí en la segunda mitad del siglo xvi y sin que se conozca, hasta la fecha, cuadro alguno de su mano. Una leyenda infundada atribuía la tabla a la Zumaya, supuesta pintora e hija del maestro del mismo nombre y casada con uno de los artistas que floreció desde finales del siglo xvi, con Baltasar de Echave Orio, al cual Díez Barroso le atribuyó también la pintura. Para Martín Soria, en correspondencia que guardo, la tabla era nada menos que del andaluz Alonso Vázquez, activo en México en los últimos años del xvi; por desgracia los días de Soria terminaron antes de que pudiera demostrar, como aseguraba, su aseveración. Pese a todos los propósitos por encontrar autor, éste queda hasta hoy sumido en el anonimato. En octubre de 1965 el cuadro fue bajado para fotografiarse; en esa ocasión y en compañía de Justino Fernández, tuve oportunidad de estudiar detenidamente la pintura, carecia de firma.

Es común en la iconografía de San Sebastián a partir del Renacimiento Italiano, el que se le represente con el varonil cuerpo desnudo y atado ya sea a una columna o al tronco de un árbol; en algunas ocasiones el santo aparece con las flechas que le clavaron sus verdugos y en otras únicamente muestra las heridas causadas por las flechas. El cuadro de la catedral de México pertenecía a esta tradición iconográfica, sin embargo, en él había una cualidad principal: la originalidad con la que su autor se ocupó del joven santo. En la pintura italiana del Renacimiento y en la correspondiente al Manierismo, he investigado sin éxito satisfactorio, un posible antecedente del cuadro hoy destruido. El antecedente más cercano está en el San Sebastián que Paolo Farinati pintó y fechó en 1576, para el Santuario de la Virgen de Frassino. ${ }^{20}$ Mis búsquedas en los grabados flamencos del mismo tema, resultaron infructuosas.

Interesado en la originalidad de la tabla mexicana y hasta donde mis investigaciones lo han permitido, he buscado un posible antecedente dentro de la pintura española de la época. Lo más próximo que he visto son dos tablas pequeñas del siglo xvi que se encuentran en la iglesia de

10 La catedral de México y..., p. 122.

20 La figura de San Sebastián forma parte de una composición mayor; Bernard Berenson publiró el cuadro de Farinati en la lámina 1922, t. IIt, de su Italian Piclures if the Renaissance. Central Italian \& North Italian Schools. Phaidon, Londres, 1968. 

DOI: http://dx.doi.org/10.22201/iie.18703062e.1970.39.916

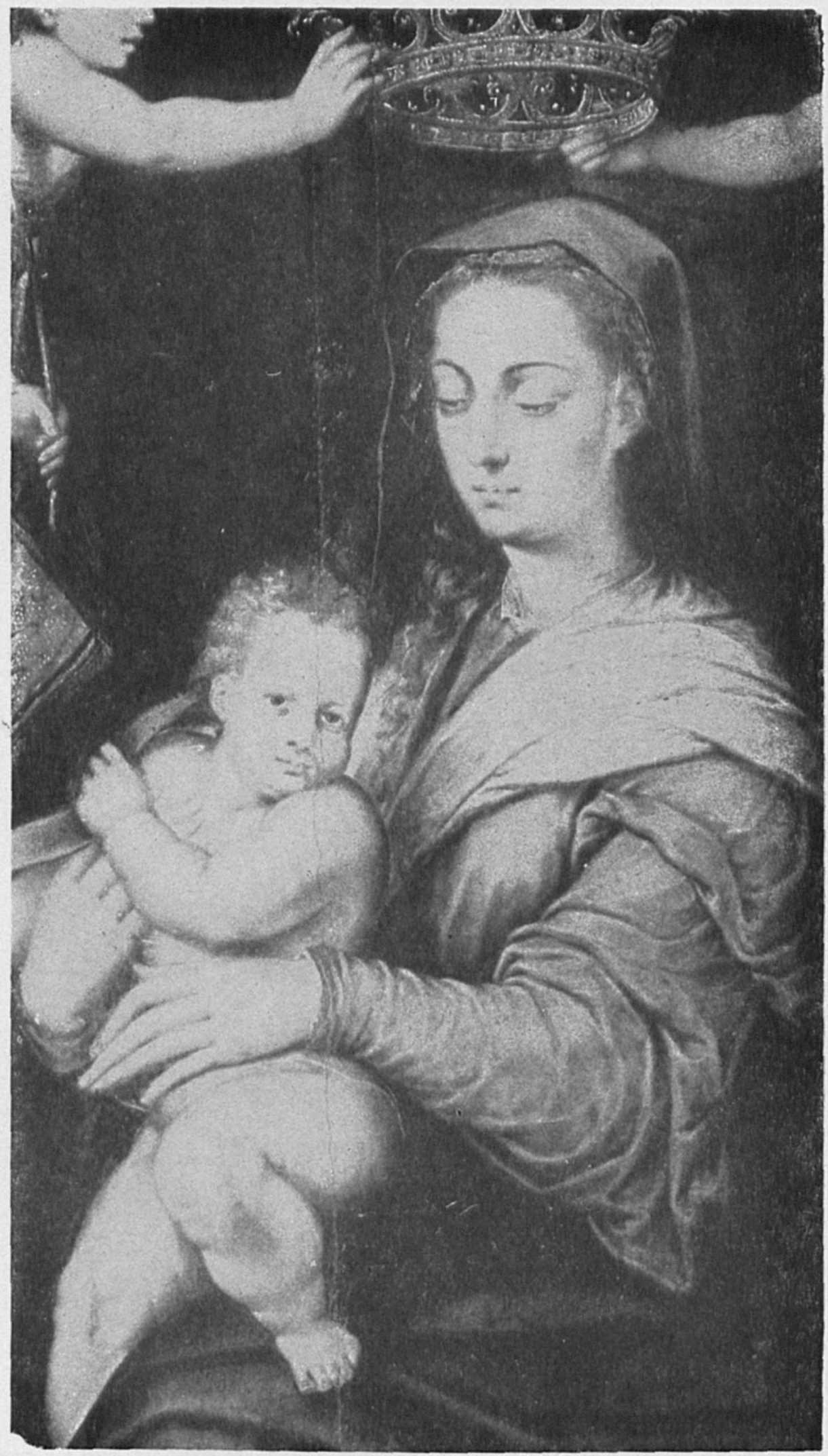

2. Simón Pereyns. Virgen del Perdón. Detalle 


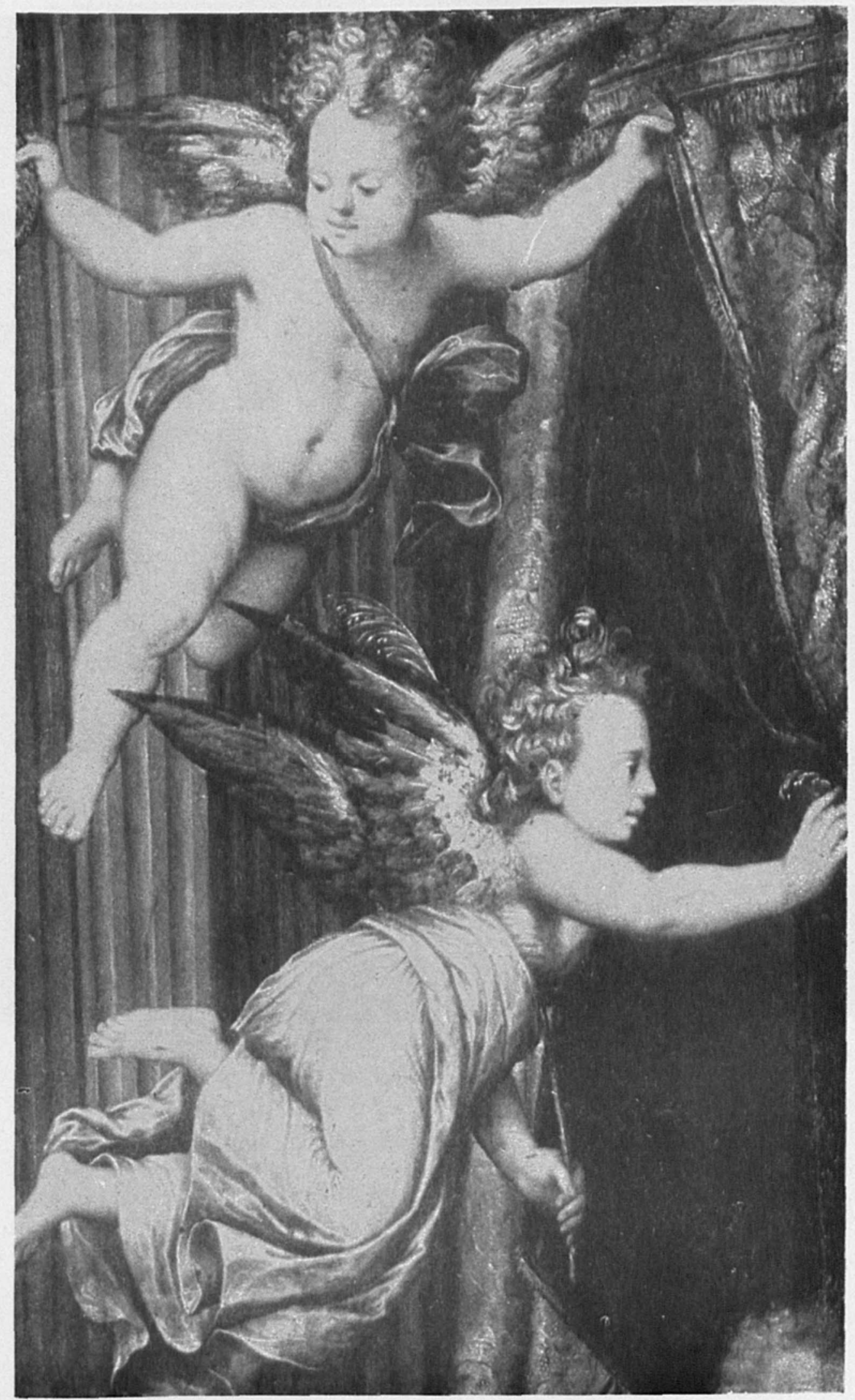




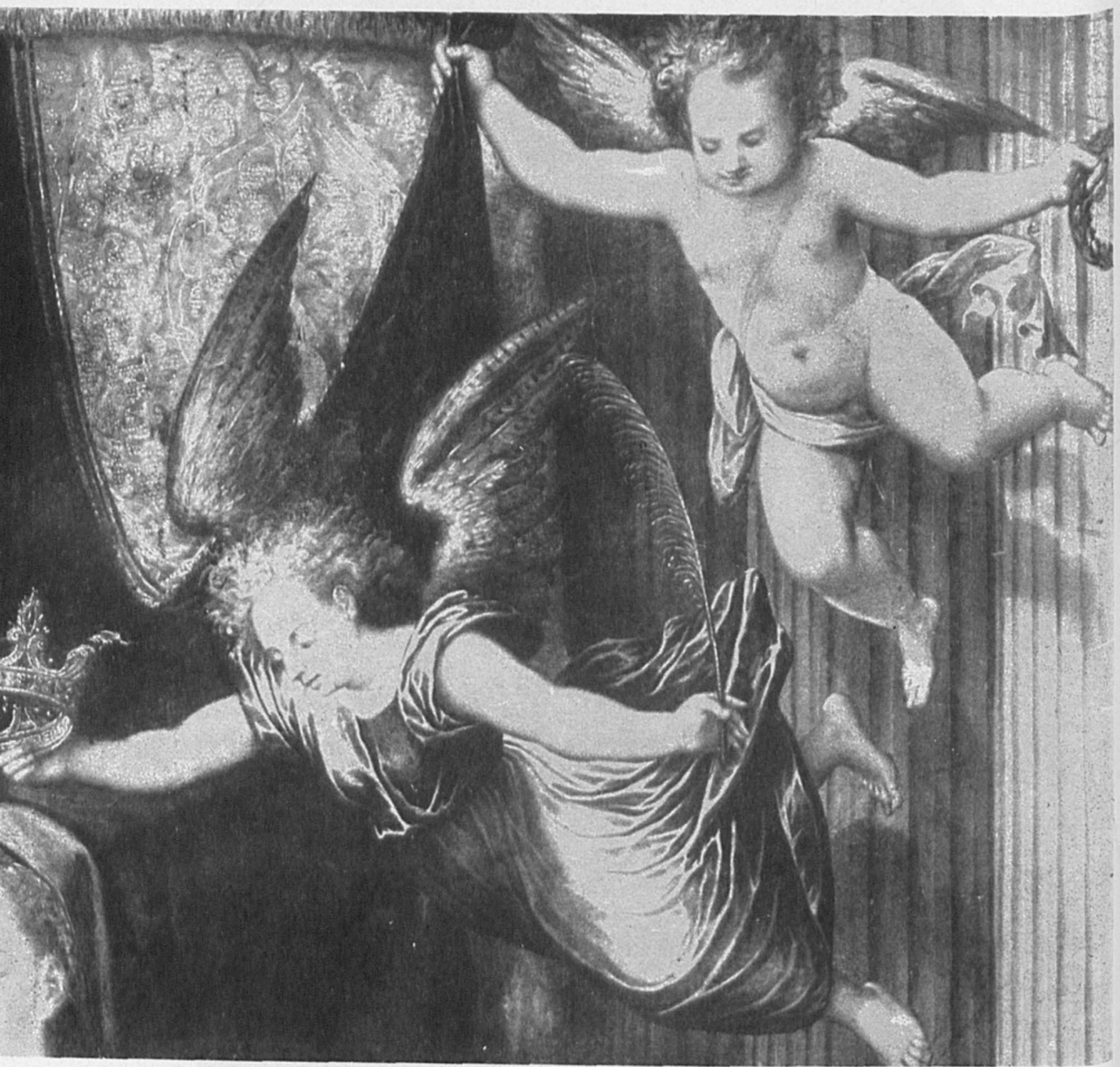

4. Simón Pereyns. Virgen del Perdón. Detalle. 
DOI: http://dx.doi.org/10.22201/iie.18703062e.1970.39.916



\section{$\mathrm{N}^{\mathrm{A}} \mathrm{S}^{\mathrm{A}}$. DEL PERDON}

Sequn se venera en la Sfa. Yylesia Cat.'2e ONex:

A dev. del P. D. Jose'M."Toral colec. de Animas en atha. S.'Y. a. 1819 .

5. Manuel Araoz. Virgen del Perdón. Grabado en lámina de cobre. 1815 
DOI: http://dx.doi.org/10.22201/iie.18703062e.1970.39.916

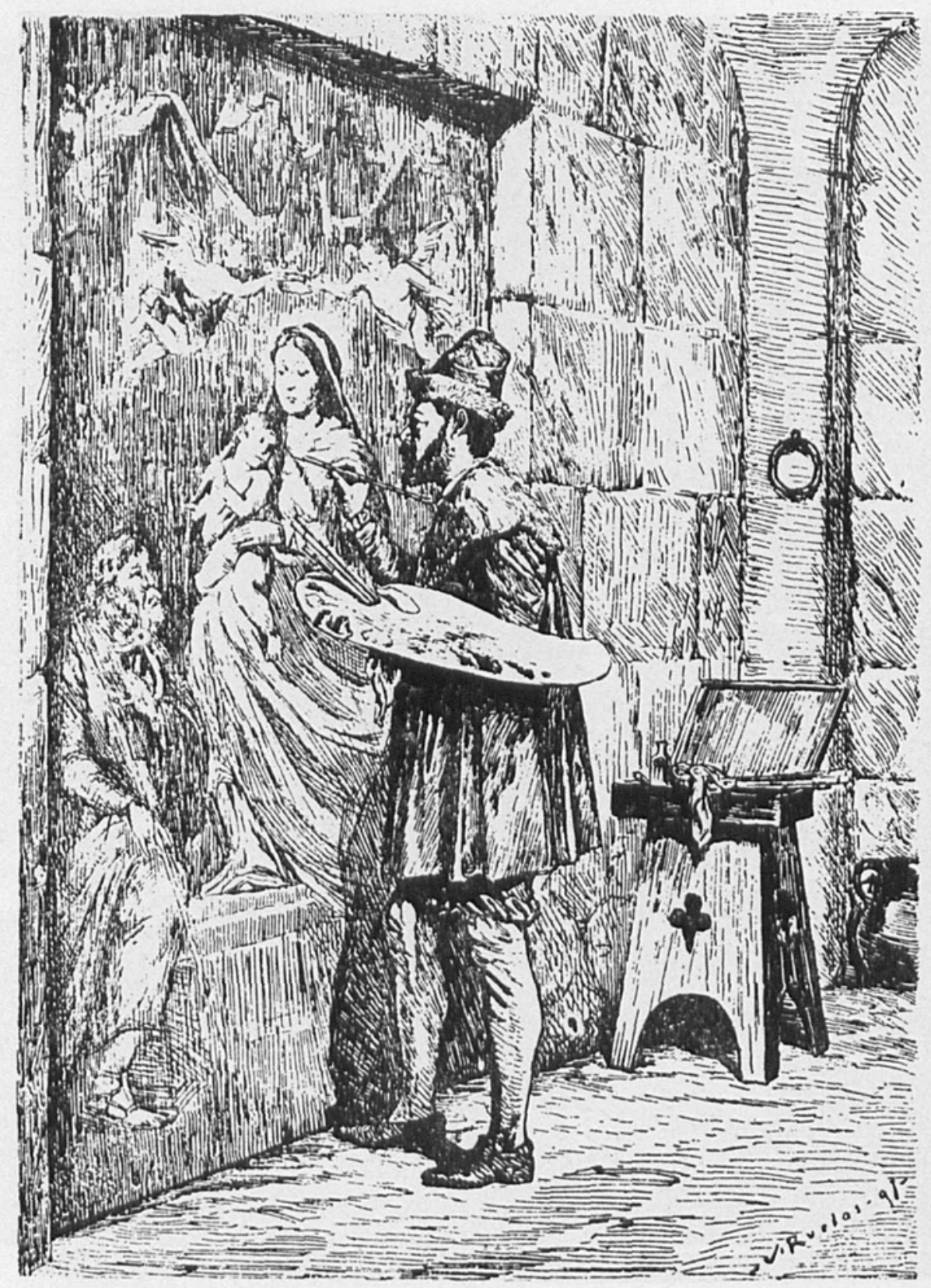

6. Julio Ruelas. Simón Pereyns pintando. Dibujo a pluma 
DOI: http://dx.doi.org/10.22201/iie.18703062e.1970.39.916

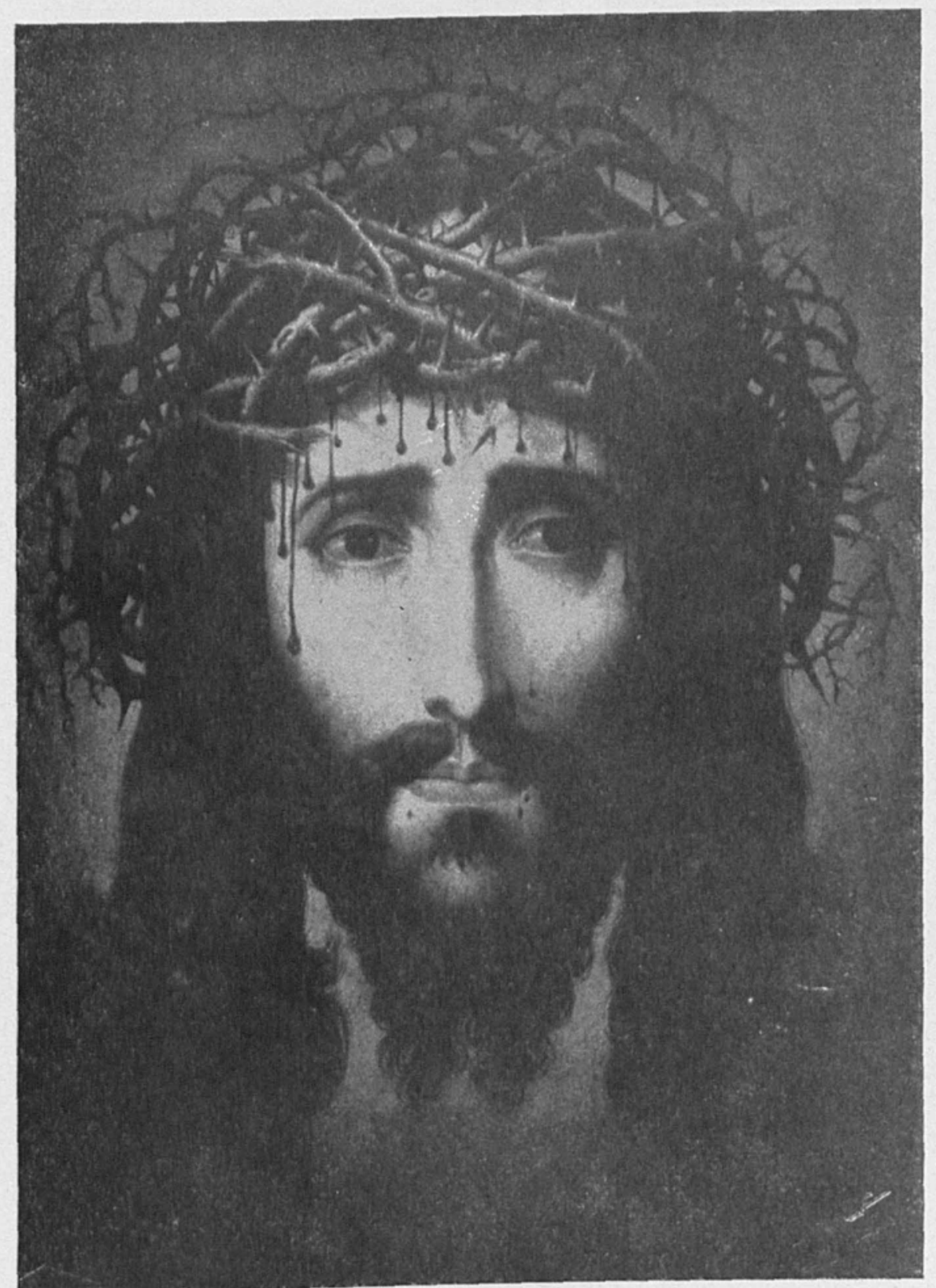

7. Alonso López de Herrera. Divino Rostro, 1634 


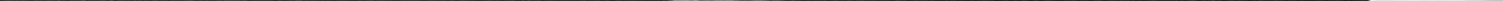


DOI: http://dx.doi.org/10.22201/iie.18703062e.1970.39.916

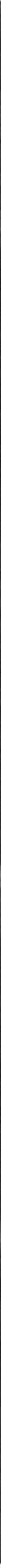

9. Anónimo. San Sebastián. Detalle 
DOI: http://dx.doi.org/10.22201/iie.18703062e.1970.39.916

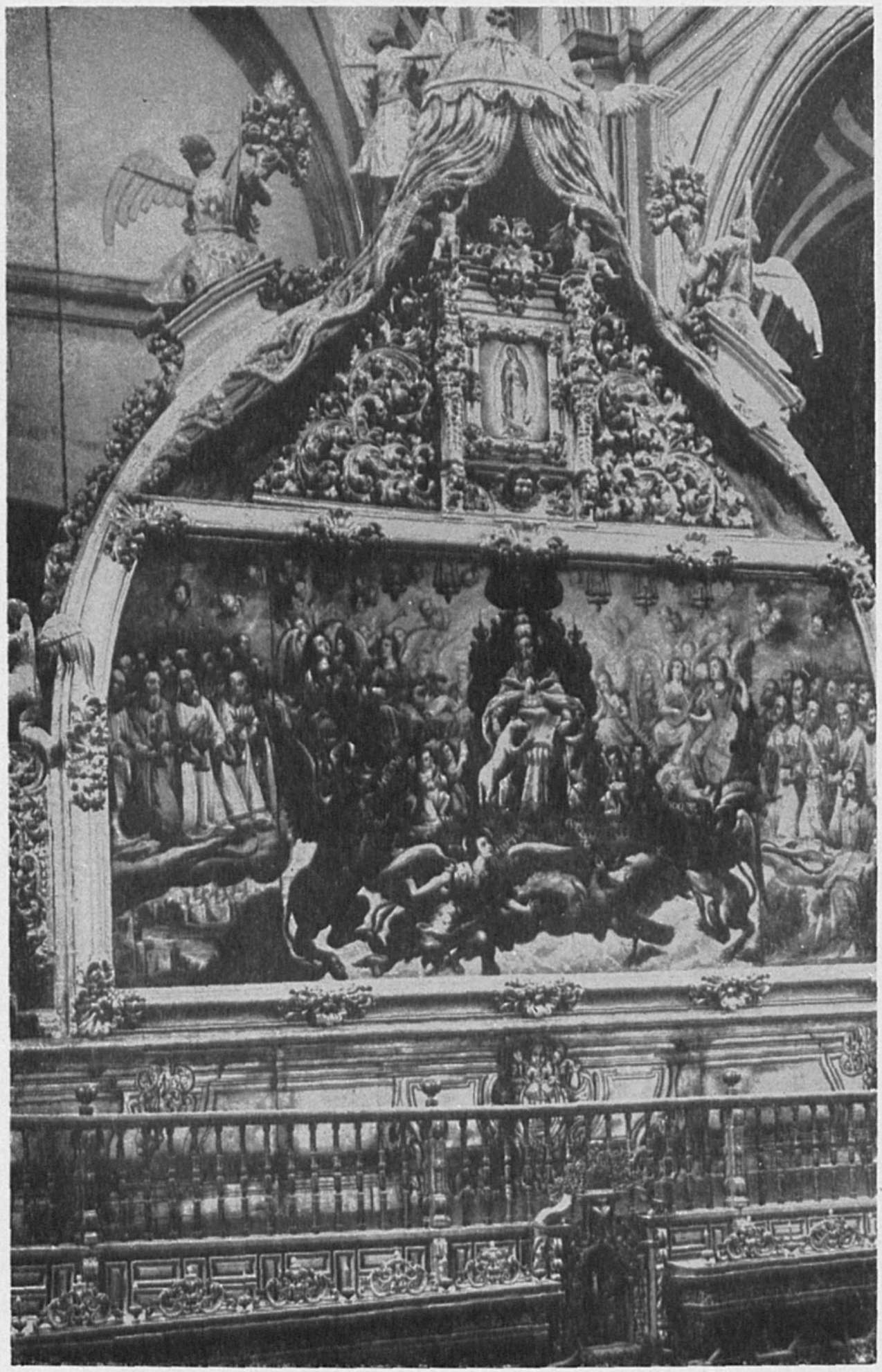

10. Juan Correa. Visión apocaliptica de San Juan. 1684 


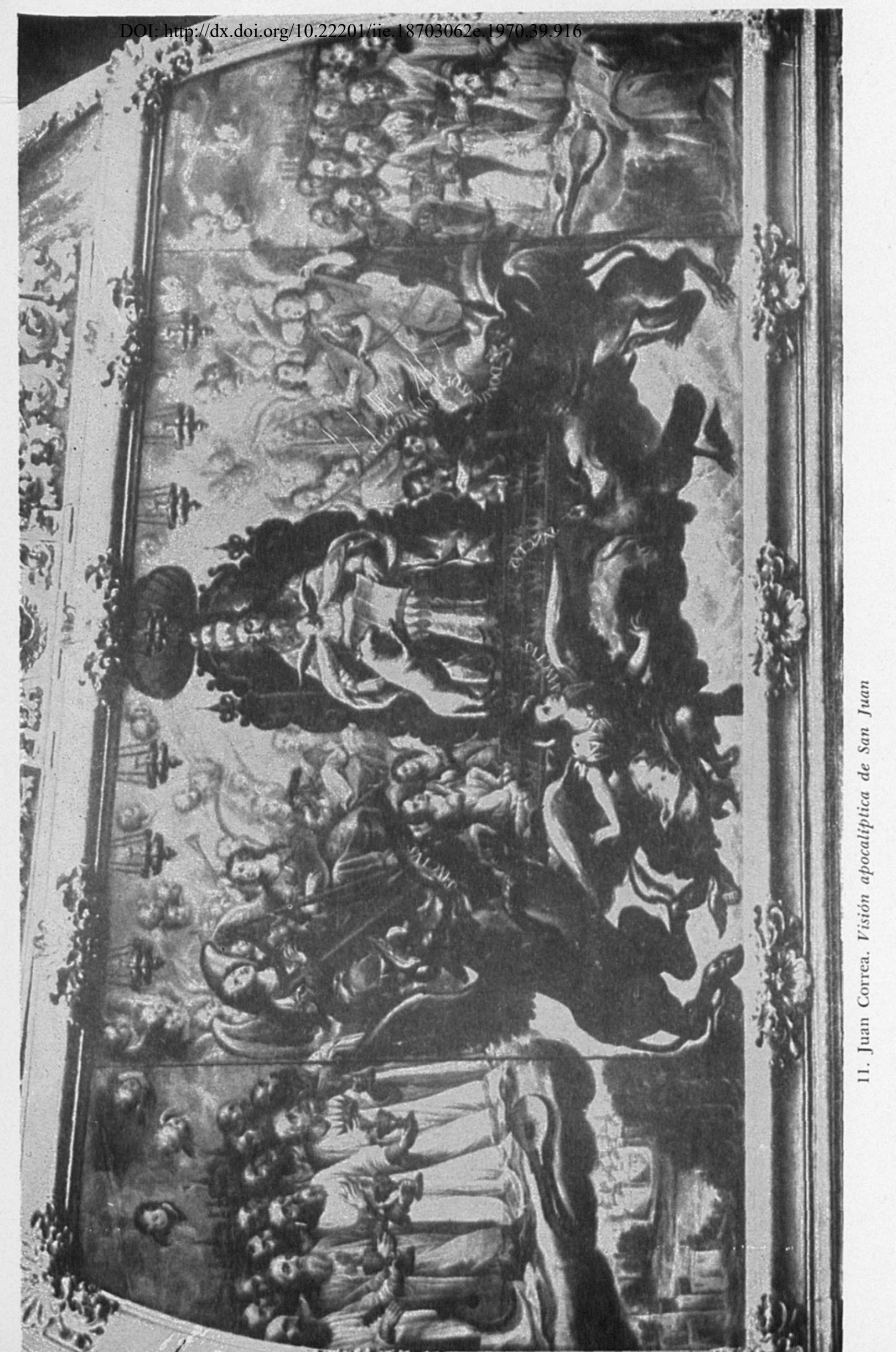


DOI: http://dx.doi.org/10.22201/iie.18703062e.1970.39.916

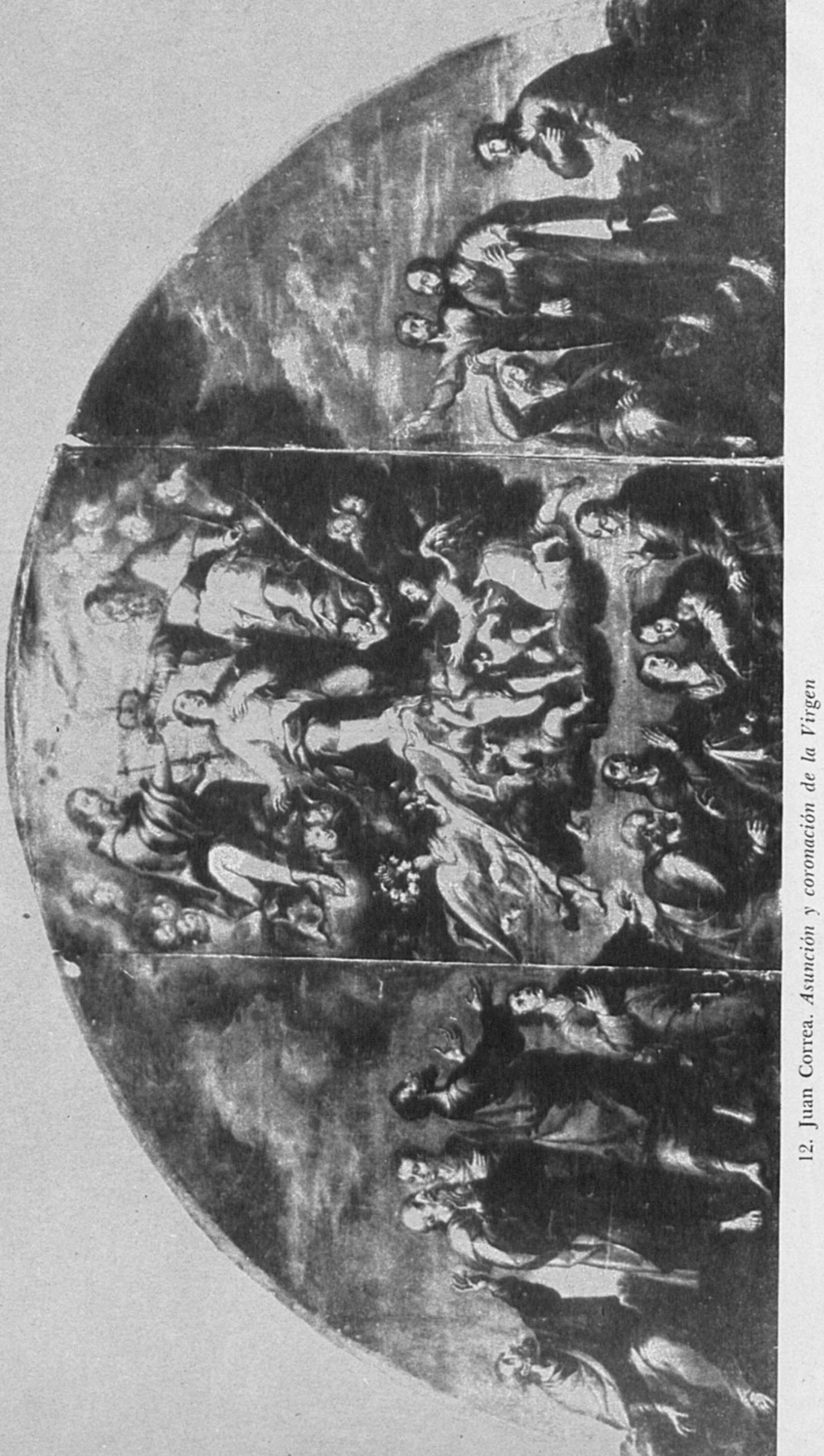


DOI: http://dx.doi.org/10.22201/iie.18703062e.1970.39.916

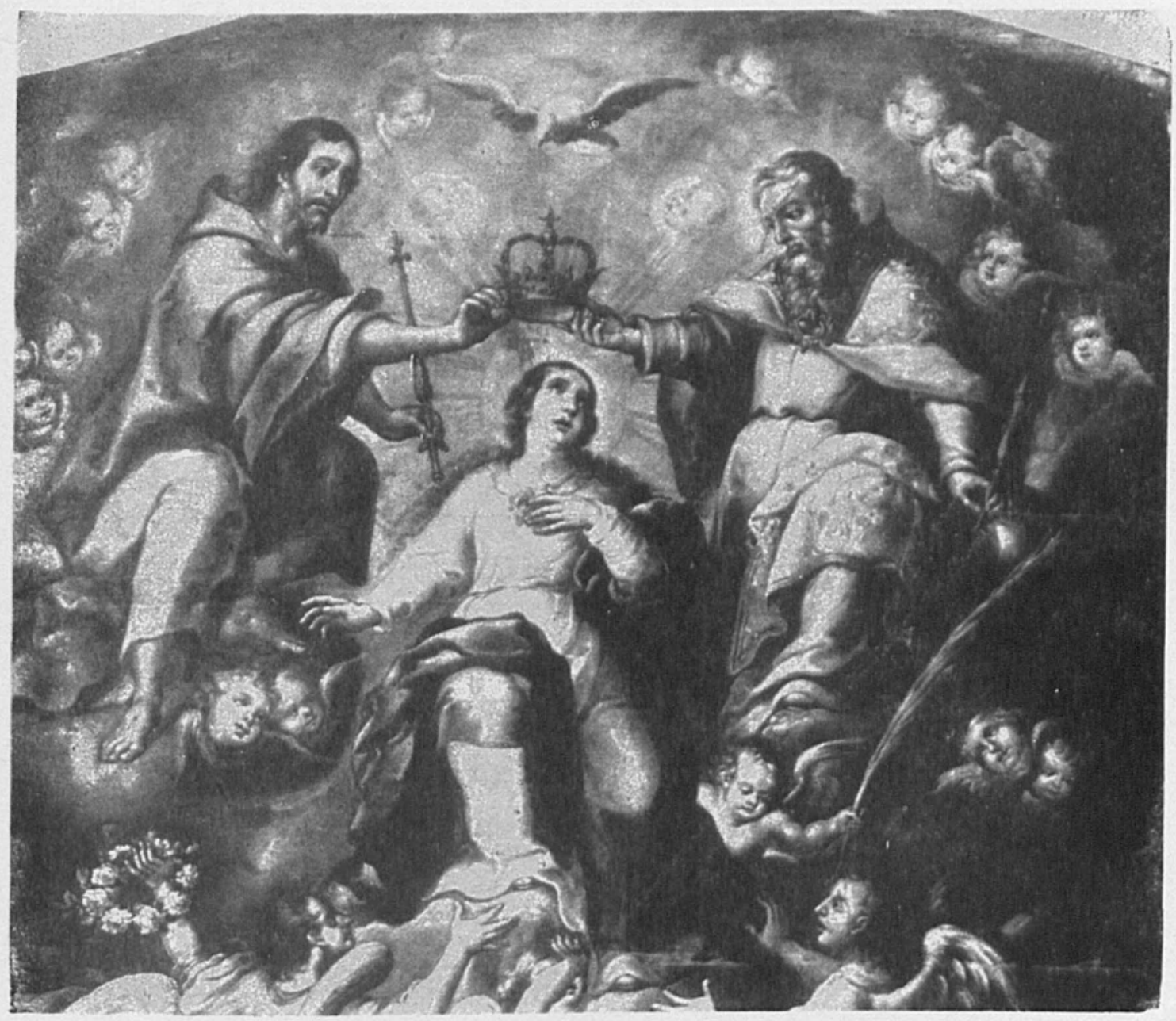

13. Juan Correa. Asunción y coronación de la Virgen. Detalle 


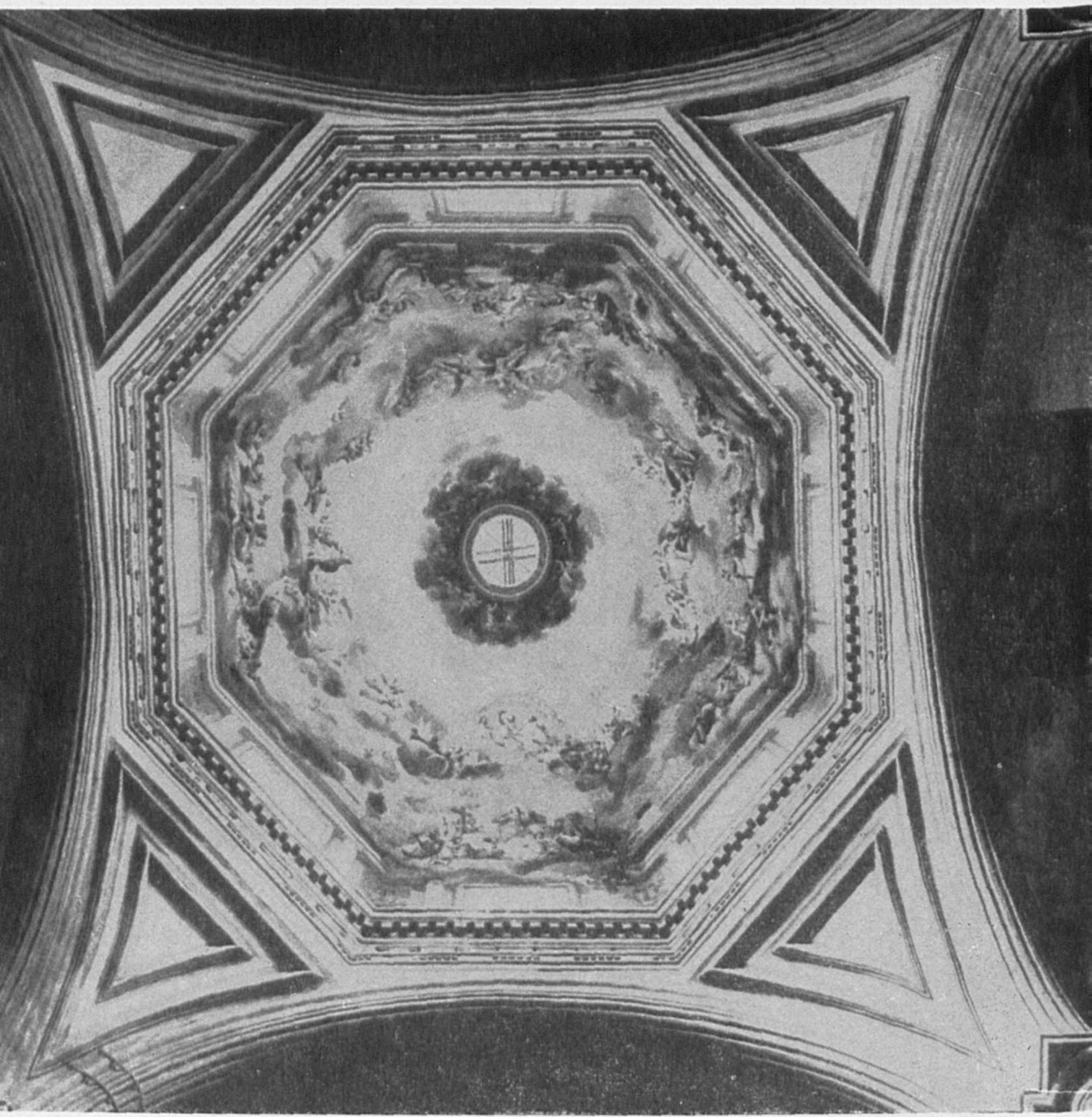

14. Rafael Jimeno y Planes. Asunción de la Virgen. 1810 


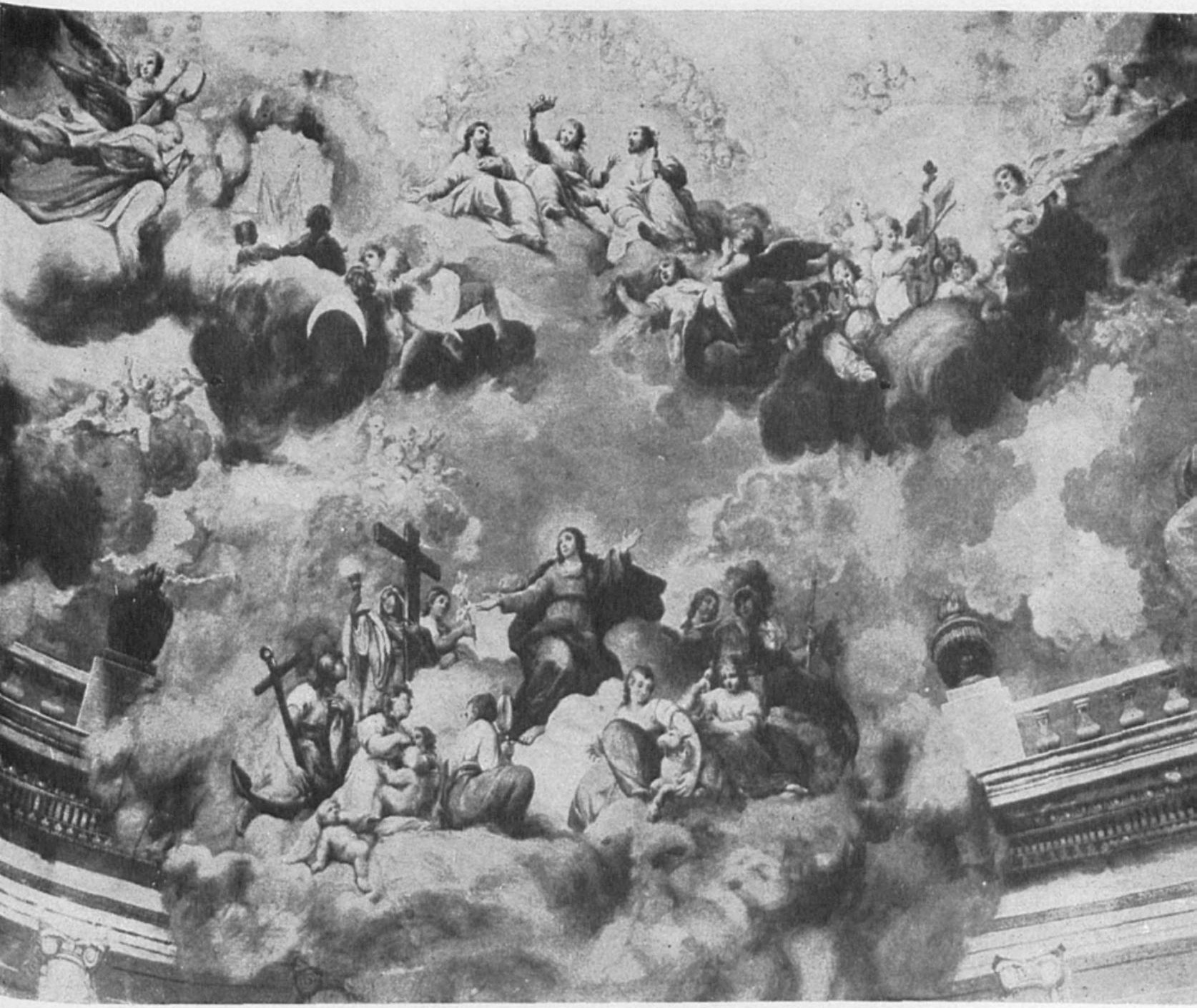

15. Rafael Jimeno y Planes. Asunción de la Virgen. Detalle 


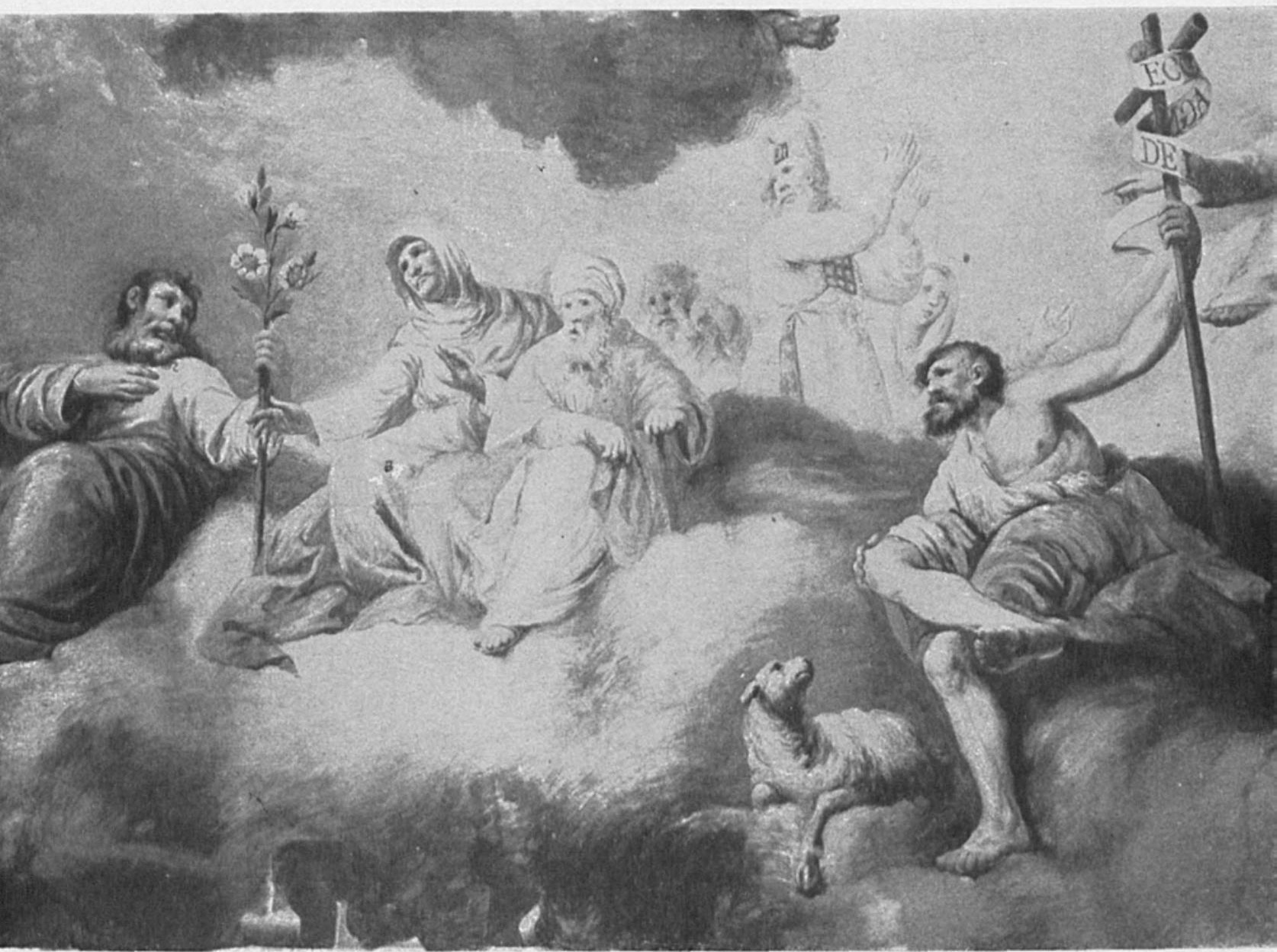

16. Rafael Jimeno y Planes. Asunción de la Virgen. Detalle 
Santa Ana en el barrio de Triana en Sevilla. Ambas pinturas son anónimas, pero el San Sebastián que está en el lado derecho del altar de San José, es muy semejante en su composición, al de México.

No es mi deseo lanzar juicios precipitados, pero sí me parece que la figura desnuda de San Sebastián no fue muy afortunada tanto en la escultura como en la pintura española, como lo fue en el arte renacentista italiano. Quizá la razón de ello radique en el temor eclesiástico ante las tentaciones que despierta la belleza desnuda del cuerpo humano y máxime si éste corresponde al de un ser joven como en el caso del santo asaeteado. Fuera de los ejemplos citados de Sevilla, solamente recuerdo dos pinturas importantes de San Sebastián, las cuales tienen en su composición un lejano parentesco con el cuadro mexicano, en ambas el santo levanta el brazo derecho sobre la cabeza y allí se detiene toda semejanza. La primera pintura pertenece a la catedral de Valencia y se debe a Pedro de Orrente; si la composición total es distinta, en cambio la figura varonil del santo no deja de recordar a la de México. Juan Carreño de Miranda pintó en 1656 el otro San Sebastián a que me refiero; el cuadro se exhibe actualmente en el Museo del Prado. Las dos grandes telas corresponden a la pintura española del siglo xvir y a ellas agrego un cuadro más del mismo siglo, cuadro perteneciente al Museo Cerralvo de Madrid y que se clasifica de escuela italiana; este San Sebastián no está muy lejos de las dos obras antes citadas.

Líneas atrás se ha anotado que el mérito principal del San Sebastián del Altar del Perdón, consistía en la originalidad con la que su anónimo autor lo pintó. Justino Fernández ha estudiado con la autoridad que le caracteriza, la estructura de la composición del cuadro. ${ }^{21}$ Sin embargo, yo deseo insistir en lo original del mismo. El santo fue visto no como un hombre joven recién salido de la adolescencia, según lo representa la tradición; por el contrario, su gallarda figura magníficamente modelada en sus distintas partes, correspondia a la de un hombre en la plenitud de su existencia; agilidad, fuerza y belleza fisica eran sus atributos. Los oscuros tonos azules que predominaban en el fondo, hacían resaltar la bella figura desnuda. Como una viril columna aparecía San Sebastián, su cuerpo descansaba con firmeza sobre la pierna izquierda, mientras la derecha se doblaba por las ataduras al árbol del sacrificio. Los brazos estaban amarrados en distintas posiciones, to cual le prestaba un movimiento levemente ondulado a la caja del cuerpo. Cuatro flechas alojadas en ese cuerpo que palpita, indican el suplicio a que se le sometió. Pero

21 Vide, nota 17. 
la nota de mayor originalidad se localizaba en el escorzo de la cabeza, llena de inspiración y sujeta a un largo cuello muy cercano al gusto de los maestros del Manierismo. El rostro del santo, inundado de fe y esperanza, se volvía hacia lo alto, hacia un rompimiento de gloria bañado por una luz dorada.

Por desgracia el brazo y la mano colocados sobre la cabeza, fueron bárbaramente restaurados hasta hacerles perder sus formas originales; pero se comprende fácilmente que quien fue capaz de pintar esa pierna y pie en que descansa el santo, no podía pintar la horrenda mano que el torpe restaurador destruyó.

El anónimo autor de esta interesante tabla había visto, conocia, la pintura veneciana, asi lo acusaban los azules de varias tonalidades del fondo; sea por coincidencia o no, pero tanto los celajes del fondo como el violento rompimiento de gloria, acusaban una influencia derivada de la escuela del Tintoretto. ${ }^{22}$

José María Marroqui anotó en su obra sobre La ciudad de México, la existencia de una copia del desaparecido San Sebastián del Altar del Perdón: "Una copia de este cuadro hecha por el célebre Rodriguez Juárez, se encuentra en la Catedral de Puebla"; ${ }^{23}$ mas se olvidó de decirnos cuál de los dos hermanos Rodríguez Juárez, Juan o Nicolás, la pintó. El citado cuadro se localiza en la capilla de las Santas Reliquias de la catedral angelopolitana; está en una altura terrible, sin embargo, se puede asegurar que no pasa de ser una obra mediocre y diferente al cuadro de México.

Alonso López de Herrera. Divino Rostro. Oleo sobre lámina de cobre. $1634(0.40 \times 0.33 \mathrm{cms}$. $)$.

La pintura manierista de la Nueva España tuvo uno de sus máximos representantes en Alonso López de Herrera, monje profeso de la Orden de Predicadores y activo como pintor por lo menos durante las tres pri. meras décadas del siglo xvır. La fama coronó con creces sus méritos al darle en vida el calificativo de "divino", quizá un tanto en atención a los cuadros que sobre el Divino Rostro pintó en repetidas ocasiones. El primer documento que se refiere al artista llamándole el "divino Herrera", es un curioso y casi desconocido impreso de 1636 . Se trata de un sermón dictado a propósito de la dedicación en la iglesia dominica de

22 El cuadro se reprodujo a color en la Pintura colonial en México, de Manuel Toussaint.

23 T, III, p. 461. 
Tepoztlán, Mor., de un retablo a Santo Domingo en Soriano; la pintura principal salió de los pinceles de López de Herrera y a ella se refiere el autor del sermón cuando dice que “... por estar nosotros tan apartados del santuario de Soriano, quizá nuestra devoción y consuelo sustituir (sic) y comunicar esta gracia a nuestro divino Herrera, que aunque en los retratos que ha hecho lo hemos visto tan acertado, en éste no hay que dudar, sino que se excedió a sí mismo..." 24 Este impreso nos ofrece tres importantes noticias sobre el pintor: la existencia de un cuadro hoy perdido, las cualidades que poseía como retratista y la honrosa distinción de llamarle "divino Herrera", tal como en España se había calificado anteriormente a otro pintor, al "divino Morales".

En el Altar del Perdón, abajo del gran cuadro de Pereyns, se encontraba un Divino Rostro, trabajado en 1634 a costa y "devoción de Francisco de Balza" (fig. 7). El cuadro debió disfrutar de cierta celebridad pues no se olvidó del mismo el bachiller Juan de Viera en su descripción de la catedral: "... un rostro de Cristo en su marco de ébano y plata, de tamaño poco más de una vara, con su penacho del mismo metal, del que he ofdo hablar no sé que particularidades, que por no constarme de ser verdad, las dejo en el tintero." 25 Lástima es que Viera no nos haya referido las "particularidades", pues asł sabríamos algo más sobre esta pintura del dominico. Manuel Romero de Terreros advirtió que López de Herrera repitió con frecuencia los temas que trató. ${ }^{28}$ Así el cuadro del Altar del Perdón no era sino uno más de la considerable serie que con ese tema pintó y de los cuales he logrado documentar hasta nueve.

En estas obras Alonso López de Herrera llegó a ser un verdadero virtuoso y es seguro que su fama descansaba en buena parte sobre ellas. Sin embargo, el tema no era del todo original, aparte de los antecedentes que tiene en la pintura italiana del siglo xv, creo que él se inspiró directamente en una lámina de procedencia alemana del círculo de gra-

24 SERMON,/EN LA DEDICA-/CIÓN DEL RETABLO, Y/ Altar de la milagrosa Ymagen de N.P. santo/Domingo Soriano de Tepuztlan./ Predicole el P. Fr. Thomas de Mesa, Vicario del/ dicho Pueblo,/ BENEDiCTUS REDEMPTOR UM-/ nium, qui saluti providens hominum mundo dedit sanctum Dominicum, Eccles. in officio Eiugdem./ Ano 1636/. (Viñeta con el escudo Dominicano) Benedicta Redemptoris omnium Mater, quae saluti/providens hominum, in effigie mundo dedit/ Sanctum Dominicum./ CON LICENCIA,/ En la imprenta de Francisco Salbago, impresor, y librero,/ en la calle de San Francisco. Debo al doctor Francisco de la Maza, el conocimiento de este raro impreso, $\mathrm{mi}$ agradecimiento desde aqui.

25 Vide: Breve compendiosa narración..., p. 35.

20 "El pintor Alonso López de Herrera", en Anales del IIE. Vol. Ix, núm. 34, p. 9, México, 1965. 
badores que se movía en torno a Durero. Estos cuadros de López de Herrera están trabajados con la minucia y el gusto que hay por la línea de trazo delicado y firme, como aparece en los grabados de los maestros alemanes. Al estudiar el Divino Rostro hoy perdido, o el cuadro semejante que se exhibe en el Museo Nacional del Virreinato en Tepotzotlán no se puede dejar de recordar el Autorretrato de Alberto Durero del Museo del Prado; como si tuviera esta célebre obra enfrente el dominico dibujó, mas que pintó, el ondulado cabello de Jesucristo, un tratamiento de idéntica forma dio al bigote y barba. De gran calidad en el dibujo es, asimismo, la corona de espinas que porta el Salvador. Por desgracia la fotografia que aquí se publica no contribuye a sostener mis aseveraciones, éstas habrá que constatarlas ante el ya citado cuadro de Tepotzotlán, fechado en 1624, diez años antes que el de la catedral.

Juan Correa. Vision apocaliptica de San Juan. Óleo sobre tela. 1684 $(6.50 \times 12.90 \mathrm{mts}$.$) .$

Juan Correa en compañía de Cristóbal de Villalpando son los maestros que mejor representan la pintura barroca de fines del siglo xviI. Los dos poseen una personalidad acusada, un estilo que los distingue e identifica individualmente en la considerable producción que tuvieron. Para la sacristía de la catedral, los dos maestros fueron llamados, se les confió el cubrir con grandes cuadros murales las paredes de la enorme sacristia. Entre 1689 y 1691 Correa pintó allí la Asunción de la Virgen, tema de su especialidad y la Entrada de Jesís a Jerusalem.

Los enormes lienzos de la sacristia no fueron las únicas pinturas que para la catedral hiciera Juan Correa; para el remate de la parte central del coro trabajó dos obras: un cuadro pequeño de la Virgen de Guadalupe y una gran composición apaisada inspirada en el Apocalipsis de San Juan. De don Manuel Toussaint son las siguientes noticias que nos informan sobre la fecha en la que el maestro habia terminado las pinturas: "... su conclusión se efectuó antes de que estuviera esculpida la sillería, pues por testimonio expedido el 20 de junio de 1684, se ordena que los jueces hacedores paguen a Juan Correa Maestro de pintor, el costo y precio de los dos lienzos que pintó para el frontispicio del Coro'." 27 Las pinturas de más está decirlo, se encontraban atrás del multicitado Altar del Perdón (figs. 10 y 11 ).

El tema encargado a Juan Correa para la enorme tela se tomó del

27 La catedral de México y..., p. 102. 
capítulo IV, versículo $2^{\circ}$, del Apocalipsis de San Juan. Los temas ins. pirados en el célebre libro de San Juan, fueron comunes al arte pictórico de la Edad Media; mas su importancia fue decreciendo a medida que las frondas del arte renacentista italiano se imponian sobre las ideas religiosas y el gusto estético. Sin embargo, entre los grabadores, los pasajes del Apocalipsis continuaron como fuentes inagotables de trabajo, toda vez que habia que ilustrar las diversas ediciones que con frecuencia continua se hacían de la Biblia, sobre todo después del movimiento luterano. Solamente queremos recordar aquí el caso, de sobra conocido, por las repercusiones gráficas de imitación que tuvieron, las láminas que Alberto Durero grabó en 1598 para el primero de sus "grandes libros", el Apocalypsis cum figuris.

En el periodo barroco que es el que a Juan Correa concierne, sólo contados temas ocuparon la atención de los artistas; desde luego la imagen del propio San Juan en el momento de la revelación, y sobre todo la Virgen del Apocalipsis; tema tratado frecuentemente por Rubens y a quien se copió en forma inmoderada, gracias a la divulgación de su obra a través de grabados. Cuadros de una concepción semejante al que pintó Correa, resultan excepcionales en la gran pintura barroca.

En el Apocalipsis de San Juan se lee: ... y vi un solio colocado en el cielo y un personaje sentado en el solio... Y alrededor del solio veinticuatro sillas y veinticuatro ancianos sentados, revestidos de ropas blancas, con coronas de oro en sus cabezas. $Y$ del solio salian relámpagos, y voces, y truenos, y siete lamparas estaban ardiendo delante del solio, que son los siete espiritus de Dios, y alrededor de él, cuatro animales... era el primero parecido al león, y el segundo a un becerro, y el tercer animal tenia cara como de hombre, y el cuarto animal semejante a un diguila volando...

Dentro de una animada composición barroca Juan Correa situó el tema central de la enorme pintura. ${ }^{28} \mathrm{El}$ solio, en este caso, era un pesado y adornado trono barroco con una enorme venera en la parte superior; Dios Padre se sentaba en él y le acompañaban la paloma del Espiritu Santo y el cordero que simboliza a la Tercera Persona. Los cuatro animales del Tetramorfos, o sean los símbolos de los evangelistas, vuelan con marcado movimiento en torno del grupo central. Los veinticuatro ancianos, vestidos de ropas blancas, reunidos en dos grupos,

28 Las dimensiones, 6.50 de altura por $12.90 \mathrm{mts}$. de largo, provienen del libro La Catedral Metropolitana de México, de Pablo Jesús Sandoval y José Ordónez, p. 124. Ediciones Victoria, México, 1938. 
aparecian en los extremos de la composición, portando en sus manos las coronas de oro y grandes copas o cálices y como instrumentos musicales llevaban no el arpa o la lira, sino guitarras. Las siete lámparas pendian de la parte superior. La figura de San Juan con el libro abierto en que escribe sobre las piernas, se encontraba en el ángulo inferior derecho; guardando un orden simétrico, en el otro extremo aparecía ...la ciudad santa de Jerusalem..., Apocalipsis, capítulo XXI, versículo 10. Correa no se apegó por completo a la descripción del texto biblico debido a ello la novedad mayor en la pintura la constituía el gran coro de ángeles músicos que introdujo, coro dispuesto a los lados del solio; el barroquismo de los ángeles y las rubicundas cabezas de los serafines saltaba a la vista.

Resulta difícil precisar hasta qué punto Juan Correa fue original en la composición de la gran tela hoy perdida; ante estos temas siempre se piensa en la procedencia de grabados europeos, colocando en la situación de pobres diablos copistas a los pintores de la Nueva España, lo cual no siempre resulta exacto. Entre el número considerable de grabados revisados sobre el Apocalipsis, no localicé alguno de composición semejante a la pintura mexicana. Mientras la probable fuente, o fuentes, no aparezca, daremos a Juan Correa la paternidad original de su visión apocalíptica de San Juan.

Hasta donde la memoria me es fiel, recuerdo que el colorido general del cuadro era de tonos fríos, con predominio de azules y grises. Un contraste violento en luces y sombras, por lo demás muy del gusto de los maestros barrocos, se localizaba tanto en el cúmulo de nubes, como en los cuatro símbolos de los evangelistas.

Juan Correa. Asunción y coronación de la Virgen. Oleo sobre tela (8 $\times 10 \mathrm{mts}$., aproximadamente).

El tema doble de la Asunción y Coronación de la Virgen, fue frecuente en la pintura virreinal a partir del último tercio del siglo xvil. Su antecedente es, desde luego, europeo, pero aquí encontró tan favorable aceptación que se pintaron infinidad de lienzos en el barroco siglo xvir.

Juan Correa pintó para la catedral un cuadro en forma de arco de medio punto, el cual por sus grandes dimensiones estaba seccionado en tres partes; tal obra se encontraba, ya se ha dicho, sobre la puerta 
mayor. Desafortunadamente no se cuenta con los datos referentes al contrato de trabajo, importe del msimo y el año en que se hizo (fig. 12).

La composición barroca de la enorme tela, estaba regida por la forma de la misma; si bien el grupo central a la altura de los ángeles y los apóstoles en pie, de los extremos, indicaban con fuerza una pronunciada curva en sentido contrario al medio punto. En la sección del centro se desarrollaba el tema mariano. La Virgen subia a los cielos sobre un cúmulo de nubes rodeado de ángeles y querubines; uno de los ángeles, de burda factura, portaba la simbólica corona de blancas flores. El rostro de la Virgen estaba inundado por una expresión de beatitud, pues al llegar a la gloria era coronada por La Trinidad, representada ésta, en la forma tradicional (fig. 13.) En la parte inferior se hallaban tres de los apóstoles en compañia de María de Cleofás y Maria Magdalena; el grupo, entre atónito y sorprendiđo, ve ascender a la Virgen desde su tumba. Sin embargo, el obligado monumento funerario no aparecía, por lo cual las cinco figuras sólo mostraban medio cuerpo, lo que producía una desagradable impresión toda vez que los nueve apóstoles restantes estaban parados en un nivel superior, sin conexión lógica con el grupo central. Este error en la composición, se debió tal vez a que la parte del centro se trabajó en forma independien. te de los extremos.

La obra no dejaba de acusar ecos lejanos de Flandes, de Pedro Pablo Rubens o de sus seguidores. De manera particular la postura de la Virgen provenía de Rubens, pues tenía una cierta semejanza con las imágenes de la iconografía asuncionista del maestro flamenco. El cuadro de la catedral de Amberes, es un ejemplo elocuente, incluso en otros detalles.

En la iconografía española sobre la Asunción, hay varias obras que recuerdan la posición en que Correa pintó a la Virgen y ángeles que la acompañan; una de ellas es el cuadro de Juan del Castillo que se exhibe en el Museo Provincial de Bellas Artes de Sevilla. Es muy posible que para el grupo central de la Asunción de María, excluyendo a la Trinidad, Juan Correa haya aprovechado un grabado que me es desconocido, pero que debió circular ampliamente entre los pintores de la Nueva España, toda vez que la figura de la Virgen es bastante semejante a la que aparece en la Asunción que Miguel Cabrera pintó en 1759, para la sacristía de Santa Prisca, en Taxco.

El gran cuadro hoy perdido, no era de lo mejor que se conoce de Juan Correa. El dibujo de las figuras era de trazo duro y descuidado. 
El grupo de los tres pequeños ángeles, de inspiración ruberiana, contrastaba por su finura, con los grandes ángeles de los extremos. Aparte del error que líneas atrás se ha indicado, las imágenes de los apóstoles que intentaban guardar una expresión de asombro, resultaban flojas, poco convincentes; como asimismo las figuras del Padre y el $\mathrm{Hijo.}$ ¿Obra de taller?, posiblemente; lo cierto es que el cuadro era inferior, en calidad plástica, al que con el mismo tema pintó en 1689, para la sacristía de la propia catedral.

Rafael Jimeno. Asunción de la Virgen. Pintura mural al temple. 1810.

El Diario de México, correspondiente al 14 de agosto de 1810 , publicó la noticia de la conclusión de las pinturas murales que Rafael Jimeno pintó en la cúpula de la catedral. El anónimo redactor de la noticia ofreció a sus lectores una descripción de las pinturas, la cual por su interés se reproduce aquí. ${ }^{29}$

Rafael Jimeno (1759-1825) de origen valenciano, figuraba como director general de la Real Academia de las tres Nobles Artes de San Carlos, de la Nueva España; no obstante los cuadros de caballete que habia hecho, retratos y asuntos religiosos, y con los que había dado muestras de su habilidad artística, se puede decir que su fama quedó asegurada para la posteridad con la decoración pue hizo en la citada cúpula, que no fue por cierto, la única que pintó, pues en 1813 trabajó

29 "Explicación de la pintura ejecutada en la media naranja de la santa iglesia Catedral de esta ciudad, que se estrenará con motivo de la solemne función de Maria Santisima en el misterio de su Asunción."

"Sobre un cuerpo de arquitectura en perspectiva, se representa a la Virgen bajo su advocación de la Asunción al cielo, acompañada de todas las virtudes, personificadas del modo más conveniente y adecuado. En la parte superior, se ven figuradas las tres simbólicas personas de la augustísima Trinidad. Dios Padre. Dios Hijo y Dios Espiritu Santo, en actitud de bajar a recibir a la Santa Virgen. En medio está el Eterno Padre con una corona en la mano. A la diestra el Hijo Redentor enseñándole el trono que tenía preparado para su Santísima Madre, compuesto de querubines, de la Arca del Testamento, la media Luna y la Estrella, y a la siniestra mano se puede contemplar al Espíritu Santo empuñando un cetro, como para hacer efecti. va la coronación de tan Soberana Reina. A los lados, pero en primer término, y del lado del Evangelio están los Santos Padres del Testamento Antiguo, y a la parte de la Epistola, la Familia Sagrada, por su orden, en ademán de alabar y bendecir aquel dulce e "incomprensible prodigio". Con el mismo fin se representan al frente todas las Matronas del Antiguo Testamento, como simbolos de María, y sobre estos grupos se descubre la Corte Celestial comandada por los tres arcángeles, San Miguel, San Gabriel y San Rafael, y cerca de la Trinidad augustísima, aparecen multitud de ángeles tocando diversos instrumentos de música, como para manifestar su regocijo y culto al criador del Universo", pp. 127-128. 
también en la capilla del Señor de Santa Teresa, cuya cúpula vino a tierra en 1845, debido a un terremoto; a esas dos obras hay que agregar el plafond que pintó entre 1812 y 1813 , para la capilla de la Escuela de Minas. Se comprende el prestigio alcanzado por Jimeno si se tiene en cuenta la importancia del edificio y las dimensiones de su cúpula, el hecho de haber desaparecido la obra similar de Santa Teresa y, sobre todo, que las pinturas de la catedral representaban la modernidad neoclásica en el arte, frente a la tradición barroca. El asunto que se dio al artista a desarrollar, fue el de la Asunción de Maria, pues ésa es la advocación de la catedral. Por Manuel G. Revilla se tienen noticias de que Jimeno contó con el auxilio de un buen equipo, en el que figuraban sus alumnos de la Academia y cita a Juan Sáenz como el principal: "Sáenz fue colaborador de Jimeno en los trabajos de la cúpula... y a él pertenece el hermoso grupo de San Miguel y los ángeles rebeldes." 30 Desgraciadamente lo permeable de la cúpula y quizá también por la técnica del temple empleada, las pinturas pronto sufrieron serios trastornos, lo que obligó a que en corto tiempo se las restaurara, con lo cual se alteraron considerablemente tanto en la forma como en el color. ${ }^{31}$

Rafael Jimeno inició su carrera artística estudiando en la Academia de San Carlos de Valencia, de donde pasó gracias a una pensión por aprovechamiento, a la madrileña de San Fernando, en donde, se viene repitiendo, estudió con Mengs; tiempo más tarde fue pensionado en la Academia de San Lucas de Roma. Jimeno poseía una sólida formación académica de inspiración neoclásica; antes de pasar al Nuevo Mundo, él vio, forzosamente, las pinturas que tanto Mengs, como Tiépolo y Giacquinto, trabajaban para los techos del Palacio de Oriente, y no sólo estas obras debió ver y comentar, sino aun las de los hermanos González Velázquez y asimismo las de Bayeu y Maella encargados también de la decoración pictórica del citado palacio. Es más, en su Valencia natal existían buenas obras de pintura mural en bóvedas y cúpulas; entre las que él conoció citamos únicamente las de la iglesia de los Santos Juanes y las que Antonio Palomino ejecutó para la Basílica de Nuestra Señora de los Desamparados y aun hay que recordar, las importantes del Colegio de Corpus Christi o del Patriarca, debidas a Bartolomé Matarana (1597). Estos antecedentes formaban sólo parte

30 op. cit., p. 146.

31 Hay noticias de dos restauraciones; en 1896 se le encargó a Tiburcio Sánchez y en 1926 los trabajos estuvieron a cargo de Armando Garcla Núnez. 
de la carga artística que traía consigo Jimeno a la Nueva España, antecedentes que debió tener presentes al encargarse de la decoración de la cúpula catedralicia.

Es extraño que no se hiciera un detenido estudio sobre la obra de Jimeno en la catedral. En casi todas las referencias existentes sobre la decoración de la cúpula, se señalan influencias ya de Tiépolo, ya de Mengs, mas no se hizo, hasta donde mis noticias llegan, un estudio completo de la gran pintura cupular; salvo la descripción del Diario de México y un breve estudio de Raúl Flores Guerrero, no existe más. ${ }^{32}$ A continuación se intenta una descripción de la obra de arte que el humo destruyó por completo; para escribirla se ha contado con el auxilio de una serie de diapositivas en color, existentes en la Filmoteca del Instituto de Investigaciones Estéticas; se han utilizado también las magnificas fotos que tomó a principios del siglo, Guillermo Kahlo, las cuales se conservan en el Archivo Fotográfico del Instituto Nacional de Antropología e Historia; quien esto escribe utiliza también sus propios recuerdos y apuntes (figs. 14, 15 y 16).

La planta de la cúpula es de forma octagonal; en el tambor y a los lados de las grandes ventanas Rafael Jimeno pintó columnas con capiteles jónicos, más un grueso cornisamiento sobre el que descansaba una balaustrada clásica con sus flameros, semejante a la que en el exterior dispuso Manuel Tolsá. Sobre esta base se desarrollaba la gran decoración. El tema central, ya se ha dicho, era el de la Asunción; sin embargo, la mayor parte de las pinturas se referían a diversos pasajes del Antiguo Testamento. Jimeno dispuso la composición a base de tres fajas o anillos; en las dos primeras se centró la importancia de la composición, con cuatro grupos principales de figuras ordenadas cardinalmente: hacia el norte se encontraba el grupo de la Asunción de María; en el lado sur aparecía el arcángel San Gabriel y a los arcángeles Rafael y Miguel les correspondia por orden, el este y oeste. La multitud de figuras

32 Raúl Flores Guerrero, "Los muralistas del siglo xix", en Artes de México, núm. 4. pp. 32-93. México, 1954.

En 1874 Eduardo A. Gibbon se ocupó de la pintura de la cúpula, mas no llegó a hacer una descripción completa de los diversos pasajes interpretados por Jimeno; sin embargo, entre las observaciones serias que hizo se encuentra la siguiente: "Ximeno, en medio de su inteligencia de artista, olvida que su cuadro mural al encontrarse en las altas regiones de la cúpula tenía que ser visto desde abajo, es decir, a una gran distancia, y en vez de haber pintado el fresco propio de una rotonda majestuosa, nos ha legado una miniatura del arte que se pierde en (las) alturas..." Vide: "La catedral de México" (Impresiones), El Artisto. T-11, p. 335, México, 1874. 
alli reunidas, estaban bien presentadas en sus escorzos y en las distintas perspectivas que ofrecían. En cuanto al tercer círculo o anillo, éste estaba colocado en la abertura de la linternilla cupular; su decoración consistía en una banda de regordetes angelillos que parecian jugar entre los pliegues de un gran lienzo color rojo.

Sobre un cúmulo de nubes que rompía violentamente la pintura arquitectónica de columnas, cornisas y balaustrada, Rafael Jimeno dispuso la Asunción de la Virgen, a quien acompañaban todas las virtudes, hacia la derecha las teologales: Fe, Esperanza y Caridad y hacia la izquierda las cardinales: Justicia, Fortaleza, Templanza y Prudencia. Separado por nubes, sobre este grupo se encontraba el de La Trinidad; el Padre levantaba en la diestra una corona, el Espiritu Santo portaba un cetro, en tanto que el Hijo señalaba hacia el trono celestial de la Virgen y los símbolos de su letanía: Puerta del cielo, Arca de la alianza, Fuente de la sabiduria, mas la obligada media luna y la estrella. Un coro festivo de ángeles acompañaba con la música de diversos instrumentos, a este primer grupo (fig. 15).

En el lado derecho y sirviendo de enlace con el grupo de San Rafael, se hallaban San José, Isabel y su anciano esposo Zacarias, el profeta Baruc y la varonil figura del Bautista, a quien siguen los profetas Isaías, Ezequiel, Jeremías y Daniel; Santa Ana y San Joaquín, cerraban el extenso grupo, sobre el cual aparecía el arcángel Rafael acompañado de Tobías y varios ángeles en inquietas posturas; un tanto abajo del arcángel, Jimeno colocó a María Magdalena, tendida con indolencia sobre las nubes, con un brazo y parte del pecho a descubierto.

De los tres arcángeles, Gabriel era el de figura más hermosa; Jimeno lo pintó de perfil; con un gracioso y delicado movimiento en el cuerpo, aparecía volando, su túnica la agitaba el viento y en la diestra portaba las azucenas simbólicas; varios ángeles con agitado vuelo, le acompañaban entre las nubes. En la banda inferior se encontraban las mujeres fuertes de la Biblia. Haciendo eje con la ágil imagen de San Gabriel, se levantaba victoriosa Judith, portando la enorme espada con la que cortó la cabeza a Holofernes. En torno a Judith se desarrollaba la historia que pregona la profetisa Débora, o sea la muerte de Sísara, general de los cananeos y enemigos del pueblo de Israel; en el extremo derecho aparecia durmiendo Sísara en el momento en que Jahel va a descargar el golpe sobre el clavo que ha colocado cerca de las sienes del odiado general; en el otro extremo se encontraba desmayada la madre de Sisara, por la noticia recibida. 
El grupo de San Miguel era el más maltratado y por tanto el que mayores alteraciones sufrió en las pésimas restauraciones a que se le sometió. Sobre un cúmulo de nubes aparecia el jefe de las milicias celestes, caminando y acompañado de varios ángeles. Levantaba la mano en señal de advertencia y amenaza hacia el sitio en que aparecía tirado sobre una nube gris, Luzbel, el ángel soberbio. En la parte inferior se hallaban reunidos de izquierda a derecha, los siguientes personajes biblicos: el Rey David y su hijo Salomón, Moisés con las Tablas de la Ley, Job durmiendo y el ángel con la escalera, fuera de lugar, toda vez que estaba colocado atrás de Moisés. Tobias aparecía de espaldas, tirado y le seguían Abraham e Isaac con su respectivo y oportuno ángel; el conjunto lo cerraban las desnudas figuras de Eva y Adán, a quienes Rafael Jimeno jamás reconocería como salidas de sus pinceles, debido a la torpe restauración.

A esta altura del tiempo resulta comprometido hablar sobre los valores cromáticos de la cúpula; los colores aplicados por Rafael Jimeno se alteraron tanto por el tiempo como por las pésimas restauraciones; otro tanto se puede decir respecto al dibujo. En general los colores empleados tenían una entonación llena de claridad, predominaba el ocre y un rosa pálido y les seguía un azul tenue; en tanto que los amarillos, rojos y verdes resultaban demasiado encendidos. Para dar volumen a los cúmulos de nubes que invadían la compasición, Jimeno abusó de los grises. El empleo de la técnica del temple resultó inapropiada en un sitio invadido por la luz violenta del cielo mexicano, los colores originales poco debieron resistir.

La composición seguida por el maestro no fue del todo acertada; una mala impresión producian los espacios vacios entre los distintos grupos de figuras. El espacio vacío de mayor proporción que dejó Jimeno, estaba comprendido entre la segunda faja de figuras y la tercera, colocada ésta en torno al ojo de la linterna cupular, el aspecto de desequilibrio que producia, era desafortunado. Manuel Toussaint señaló con insistencia, que Rafael Jimeno, en la cúpula, rompió "con la arquitectura en vez de acusarla como hubiera hecho un artista del Renacimiento y hace que una gloria penetre al edificio por el espacio hueco, que deja el tambor del cimborrio; éste desaparece en la lucha de dos artes que fueron hermanas y ahora se juzgan enemigas". ${ }^{33}$

Con la decoración de la cúpula de la catedral de México, Rafael Ji33 Vide, Pintura Colonial.... p. 206. 
meno cerró prácticamente, en un año clave, la pintura de de la Nueva España. Fue una desgracia para el arte de México que tal obra se perdiera con otras valiosas pinturas y conjuntos escultóricos, como el Altar del Perdón y la sillería del coro.

\section{APENDICE}

Como apéndice a la pintura de Simón Pereyns, se incluye aqué la composición poética que a la Virgen del Altar del Perdón, dedicó Juan de Dios Peza. El poeta recogió la tradición de que se ha hablado y la compuso a su manera, alterando, sin mayor preocupación, el nombre del artista, pues éste deja de ser Pereyns, para convertirse en Peyréns; sin embargo, no olvidó de anotar que el cuadro se encontraba "en al altar consagrado/para perdón de las ánimas".

Debo el conocimiento de esta obra de Peza, a la doctora Clementina Díaz y de Ovando, a quien doy desde aquí las más cumplidas gracias. El poema se encuentra en el libro Leyendas históricas de Juan de Dios Peza. Biblioteca poética. Garnier Hermanos. Paris, s/f.

\section{EL ALTAR DEL PERDÓN}

Tradición del siglo XVI

Cuando a gobernar el reino de la rica Nueva España vino el marqués de Falcés o don Gastón de Peralta,

trajo entre su comitiva a un pintor de mucha fama, que era portugués de origen, pero educado en Italia.

Según las crónicas rezan, Simón Peyréns se llamaba; hombre de estrechos recursos y de conciencia muy ancha.

En mostrar sus opiniones cuidábase poco o nada, y una vez dijo en la corte ante donceles y damas:

"No he de mojar mis pinceles para pintar cosas santas que cuanto le atañe al cielo mi paleta lo rechaza."

No faltó quien al oirlo con miedo se santiguara, $y$ de hereje $y$ judaizante le diera en la corte fama. 
Del Arzobispo a noticia llegaron esas palabras, y del Virrey con permiso llamó a Peyréns a su casa.

Preguntóle si era cierto lo que todos murmuraban, y el pintor, sin inmutarse, y mirándole a la cara,

Repuso: "Señor, es cierto; yo pinto cosas profanas, porque las cosas del cielo ni me inspiran ni me agradan."

El prelado ordenó al punto que a un calabozo llevaran al hereje, para darle digno castigo a su falta.

Ya preso en un calabozo, después de algunas semanas, frente al potro del tormento de que se desdiga tratan.

Pero el pintor era altivo, con mucho temple en el alma, $y$ en medio de sus verdugos ratificó sus palabras.

Entonces, con grande encono, sobre la rueda le atan, y hacen que crujan sus huesos a cada vuelta forzada.

Pero como no se queja, ni ruega, ni se retracta, ordenan que se le aplique otro martirio: el del agua.

Le introducen en la boca hasta tocar su garganta el tosco embudo, por donde vierten, con siniestra calma, tres pintas que equivalian a tres gigantescas jarras.

Eran vanos los esfuerzos para evitar apurarla, pues pusieron los verdugos (conforme a sus ordenanzas), un lienzo empapado y tosco del mártir sobre la cara. 
Sufrió Peyréns el suplicio, y cuando ya agonizaba, lo volvieron a su celda sin la remota esperanza de encontrárselo con vida al despuntar la mañana.

Con gran asombro de todos, después de tan negra infamia, el artista quedó sano, sin que los jueces lograran que se desdijera nunca temiendo sus amenazas.

Dictóse al fin su sentencia, por la cual lo condenaban a sufrir prisión perpetua sin salir de Nueva España: y que tan sólo sería tal sentencia revocada en caso de que el hereje algún retablo pintara, de la Iglesia en desagravio y honrando a la Virgen santa.

Peyréns se mantuvo firme, sufrió una prisión muy larga; hasta que triste y cansado de una vida tan precaria, como en sus mejores tiempos se levantó una mañana en busca de sus pinceles, de su paleta olvidada, $y$ de todo cuanto fuera para trabajar un arma.

No hallando tela dispuesta ni manera de arreglarla, la puerta del calabozo se le ofreció a sus miradas; y en ella pintó una Virgen que embelasaba al mirarla.

Cuando concluyó tal obra, digna de la eterna fama, mandó aviso al Arzobispo, quien fue a la prisión con ansia, temiendo que aquel hereje la religión mancillara. 
Llegó el prelado a la celda, los ojos airado clava en la pintura del preso, y al ver la expresión seráfica, y la sonrisa apacible, y la celestial nurada de la imagen, se arrodilla, reza humilde una plegaria, $y$ admirado y satisfecho ordena que libre salga aquel pintor, que ha sabido honrar a la Virgen santa.

$Y$ al mismo tiempo dispone, que como pintura sacra a la Catedral se lleve la puerta privilegiada, do pintar plugo al artista a la Madre de las Gracias.

Que se le ponga, asi mismo, un ancho marco de plata $y$ un cristal, que la resguarde del tiempo y sus asechanzas; y se coloque y venere con piedad y con constancia, en el altar consagrado para perdón de las ánimas.

Han corrido varios siglos, y la Catedral aún guarda en el mismo altar, el cuadro que aquel portugués pintara.

Y cuántos de los devotos que all elevan sus plegarias, ignoran que es una puerta por un mártir decorada, más bien que con los pinceles con el dolor $y$ las lágrimas. 


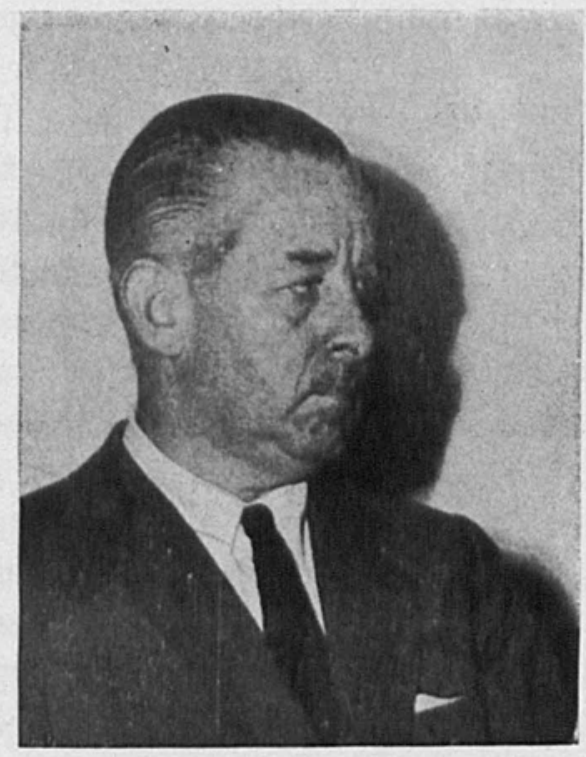

MARIO J. BUSCHIAZZO

$1902-1970$

Ha fallecido en Buenos Aires, ciudad de la que era originario, el arquitecto Mario J. Buschiazzo. Con su desaparición los estudios del arte hispanoamericano pierden a uno de sus más constantes divulgadores y el arte argentino, en particular, a un investigador insustituible.

Mario J. Buschiazzo se graduó de arquitecto en la Universidad de Buenos Aires en 1927. A la práctica de su profesión pronto agregó sus actividades como restaurador de los edificios históricos y artísticos de Argentina; la primera obra en que intervino con resultados satisfactorios fue en el Cabildo de Buenos Aires. Su labor docente es digna de toda alabanza, se puede decir que nunca se alejó de la cátedra universitaria, en las distintas disciplinas que atendió, todas relacionadas con la historia del arte en general, de la arquitectura y el arte hispanoamericano. Dictó conferencias y cursos breves, como profesor invitado en diversas universidades e instituciones culturales, tanto de Europa como de América. Recibió honores de varias corporaciones académicas, que lo recibieron como miembro.

En el terreno de la investigación de la arquitectura argentina e hispanoamericana, dejó una obra de consideración en los artículos y libros que escribió a partir de 1935. Si en Mario J. Buschiazzo había un apasionado estudioso de la arquitectura del pasado, no era menor su 
interés por la arquitectura contemporánea, de la que se ocupó en repetidas ocasiones.

En 1946 fundó el Instituto de Arte Americano e Investigaciones Estéticas, adscrito a la Facultad de Arquitectura y Urbanismo de la Universidad de Buenos Aires. Su labor editorial al frente del Instituto, del que fue director hasta su muerte, es encomiable en todos sentidos, si no se olvidan las circunstancias en que llevó a cabo esa labor. Entre esas publicaciones sobresalen los Anales, con veintidós números aparecidos hasta 1961; en ellos se encuentran trabajos imprescindibles para la historia artística de la América Española.

Mario J. Buschiazzo fue un colega y un amigo muy estimado de los niembros de este Instituto de Investigaciones Estéticas. El Instituto por él fundado en Buenos Aires, en cierta forma nació a semejanza del nuestro y de la amistad que le unía con don Manuel Toussaint. En distintas ocasiones visitó México como profesor huésped y ocupó la cátedra de Arte Colonial en la Facultad de Filosofía y Letras. En 1953 la Universidad Nacional Autónoma de México lo distinguió nombrándole Doctor Honoris Causa.

X. M. 